\title{
CLONAGEM DO cDNA QUE CODIFICA \\ A ENZIMA UDP-GLICOSE PIROFOSFORILASE \\ DE BATATA (Solanum tuberosum L.)
}

\author{
GUNTA GUTMANIS
}

\begin{abstract}
Dissertação apresentada à Escola Superior de Agricultura
"Luiz de Queiroz", Universidade de São Paulo, para obtenção do título de Mestre em Agronomia, Área de Concentração: Genética e Melhoramento de Plantas.
\end{abstract}

P I R A C I C A B A

Estado de São Paulo - Brasil

Novembro - 2003 


\title{
CLONAGEM DO cDNA QUE CODIFICA \\ A ENZIMA UDP-GLICOSE PIROFOSFORILASE \\ DE BATATA (Solanum tuberosum L.)
}

\section{GUNTA GUTMANIS}

Bióloga

\author{
Orientador: Prof. Dr. CARLOS ALBERTO LABATE
}

\begin{abstract}
Dissertação apresentada à Escola Superior de Agricultura
"Luiz de Queiroz", Universidade de São Paulo, para obtenção do título de Mestre em Agronomia, Área de Concentração: Genética e Melhoramento de Plantas.
\end{abstract}

P I R A C I C A B A

Estado de São Paulo - Brasil

Novembro -2003 
Dados Internacionais de Catalogação na Publicação (CIP) DIVISÃO DE BIBLIOTECA E DOCUMENTAÇÃO - ESALQ/ USP

\author{
Gutmanis, Gunta \\ Clonagem do cDNA que codifica a enzima UDP-glicose pirofosforilase de batata (Solanum \\ tuberosumL.) / Gunta Gutmanis. - - Piracicaba, 2003. \\ 63 p. : il. \\ Dissertação (mestrado) - - Escola Superior de Agricultura Luiz de Queiroz, 2003. \\ Bibliografia. \\ 1. Batata 2. Bioquímica 3. Biotecnologia de plantas 4. Celulose 5. Clonagem \\ complementar 7. Enzimas 8. Polissacarídeos I. Título \\ 6. DNA \\ CDD 633.491
}

'Permitida a cópia total ou parcial deste documento, desde que citada a fonte - O autor" 
Em memória de meus amados pais Ansis e Erna

Gutmanis, pelo amor e carinho dedicados e pela orientação que deram à minha vida,

\section{DEDICO}

Aos meus queridos filhos André e Liane,

OFEREÇO 


\section{AGRADECIMENTOS}

Agradeço a todos aqueles que direta ou indiretamente contribuíram na realização deste trabalho, em especial:

Ao Prof. Dr. Carlos Alberto Labate, pela oportunidade, orientação e confiança em mim depositada;

À Dra. Mônica Teresa Veneziano Labate, pela paciente orientação e incondicional assistência;

Ao Dr. David Henry Moon, pelas sugestões e auxílio na área de bioinformática;

A todos os funcionários, pós-graduandos e estagiários do laboratório de Genética Fisiológica, pela constante alegria, amizade e apoio;

Ao Laboratório de Biologia Celular e Molecular - CENA/USP, pelo sequiênciamento de DNA;

À CAPES (Coordenação de Aperfeiçoamento de Pessoal de Nível Superior), pela concessão de bolsa de estudo para a realização deste trabalho;

À FAPESP (Fundação de Amparo à Pesquisa do Estado de SP), pelo auxílio financeiro à execução desse projeto;

À Companhia Suzano de Papel e Celulose, pelo suporte técnico;

À minha querida irmã Daina Gutmanis, sempre tão presente em minha vida, pelo grande estímulo dado para o progresso em minha carreira;

Ao meu "companheiro de jornada", Jandi Augusto de Lira, pelo amor dedicado, pelo apoio às minhas decisões, e por compreender a minha ausência. 


\section{SUMÁRIO}

Página

ABREVIATURAS E SÍMBOLOS................................................................. vii

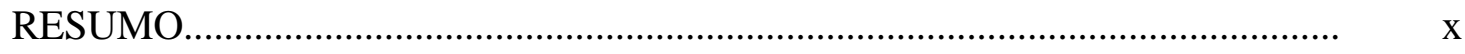

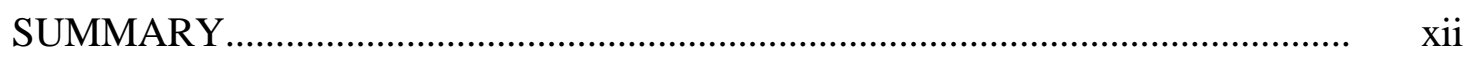

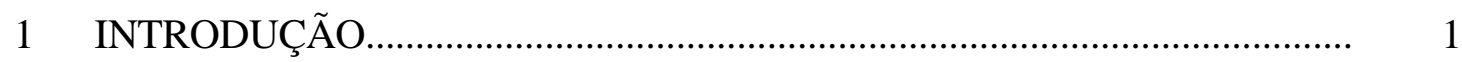

2 REVISÃO DE LITERATURA............................................................... 3

2.1 Enzima UDP-glicose pirofosforilase ..................................................... 3

2.2 Biossíntese de componentes da parede celular................................................. 4

2.3 Métodos de clonagem............................................................................ 8

2.4 Clonagem do gene da UGPase ................................................................... 9

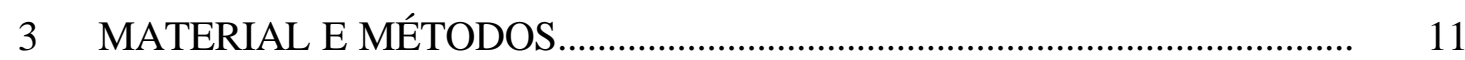

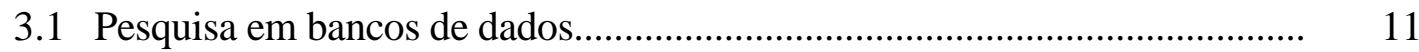

3.2 Definição dos primers para a ORF............................................................... 13

3.3 Extração de RNA total..................................................................................... 14

3.4 Purificação de mRNA a partir de RNA total................................................... 16

3.5 Reação de RT-PCR ............................................................................... 17

3.6 Clonagem no vetor TOPO................................................................... 18

3.7 Transformação química de células competentes de E. coli............................ 21

3.8 Análise por PCR das colônias transformantes............................................. 21 
3.9 Extração de DNA plasmidial......................................................................... 22

3.10 Seqüenciamento de DNA plasmidial........................................................ 22

3.11 Análise do seqüenciamento do plasmídeo.................................................. 23

3.12 Verificação de domínios conservados...................................................... 23

3.13 Extração de DNA genômico..................................................................... 24

3.14 PCR com primers específicos para a ORF............................................. 25

3.15 Análise dos sítios de restrição................................................................ 26

3.16 Southern blot ................................................................................... 26

4 RESULTADOS E DISCUSSÃO

4.1 Pesquisa em bancos de dados................................................................. 29

4.2 Similaridade entre as UGPases de algumas espécies vegetais....................... 29

4.3 Similaridade entre UGPases de alguns cultivares de batata.......................... 32

4.4 Definição dos primers para a ORF.............................................................. 36

4.5 Reação de RT-PCR ................................................................................ 37

4.6 Análise de colônias transformantes por PCR................................................. 38

4.7 Seqüenciamento de DNA plasmidial............................................................... 39

4.8 Blast da seqüência do gene com o NCBI...................................................... 42

4.9 Verificação de domínio conservado................................................................... 43

4.10 PCR de DNA genômico de E.grandis com primers de UGPase da batata. 43

4.11 Southern blot ..................................................................................... 45

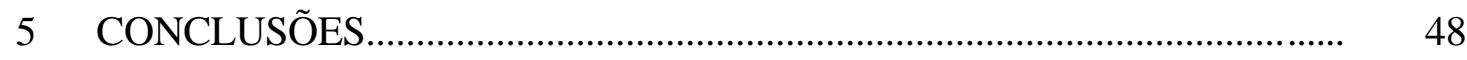

ANEXOS

REFERÊNCIAS BIBLIOGRÁFICAS............................................................ 58 


\section{ABREVIATURAS E SÍMbOLOS}

$\mathrm{A}_{260}$ ou $\mathrm{A}_{280}$ Absorbância a 260 ou $280 \mathrm{~nm}$ de comprimento de onda

BLAST Basic Local Alignment Search Tool

BSA

Albumina sérica bovina

cDNA

DNA complementar ao mRNA

cds

Coding sequence (concatenação de éxons)

CIA

Mistura de clorofórmio e álcool isoamílico (24:1 v/v)

CTAB Brometo de cetiltrimetilamônio

DEPC Dietilpirocarbonato

DNA Ácido desoxiribonucléico

dNTPs Desoxirribonucleotídeos trifosfato

EC Código da enzima dado pela Enzyme Commission

EDTA Ácido etileno diamino tetracético

$\mathrm{g}$

Grama

$\mathrm{x} g$

Força Centrífuga Relativa à aceleração padrão de gravidade

gi

GenInfo Identifier (identificador de uma seqüência de nucleotídeos)

IUB

International Union of Biochemistry

IUPAC

International Union of Pure and Applied Chemistry

$\mathrm{kb}$

Quilobase (mil pares de bases)

$\mathrm{kDa}$

Quilo Dáltons

$\mathrm{L}$

Litro

LB

Meio de cultura Luria-Bertani

M

Molar 
mg

MilliQ

$\mathrm{ml}$

$\mathrm{mM}$

MOPS

mRNA

NCBI

ng

$\mathrm{nm}$

Oligo (dT)

ORF

$\mathrm{pb}$

PCR

Pfam

pmoles

primer

$\mathrm{p} / \mathrm{v}$

PVP

q.s.p.

RNA

RNase

rpm

RT-PCR

SDS

Taq

$\mathrm{Tm}$

Tris

$\mathrm{U}$

UDP

UGPase
Miligrama

Água destilada deionizada e estéril por filtragrem a $0,2 \mu \mathrm{m}$

Mililitro

Milimolar

Ácido 3-(N-morfolino) propano sulfônico

RNA mensageiro

National Center for Biotechnology Information

Nanograma $\left(10^{-6}\right.$ grama $)$

Nanômetro

Oligo desoxitimidina trifosfato (oligonucleotídeo poli-T)

Sequiência aberta de leitura (open reading frame)

Pares de bases

Reação em cadeia da polimerase

Protein family

Picomoles

Oligonucleotídio iniciador

Peso por volume

Polivinilpirrolidone

Quantidade suficiente para

Ácido ribonucléico

Ribonuclease

Rotações por minuto

Síntese de cDNA por uma transcriptase reversa, seguida de PCR

Dodecil sulfato de sódio

DNA polimerase da bactéria Thermus aquaticus

Melting temperature

Tris-hidroximetil-aminometano

Unidades de enzima

Uridinedifosfato

UDP-glicose pirofosforilase 


$\begin{array}{ll}\mathrm{v} / \mathrm{v} & \text { Volume por volume } \\ \mu \mathrm{g} & \text { Micrograma }\left(10^{-3} \text { grama }\right) \\ \mu \mathrm{l} & \text { Microlitro }\left(10^{-3} \text { mililitro }\right) \\ \mu \mathrm{M} & \text { Micromolar } \\ \lambda & \text { DNA do fago lambda (marcador de peso molecular) }\end{array}$




\title{
CLONAGEM DO cDNA QUE CODIFICA A ENZIMA UDP-GLICOSE PIROFOSFORILASE DE \\ BATATA (Solanum tuberosum L.)
}

\author{
Autora: GUNTA GUTMANIS
}

Orientador: Prof. Dr. CARLOS ALBERTO LABATE

\section{RESUMO}

A biotecnologia está revolucionando a atividade human nas mais diversas áreas. No setor florestal, as novas tecnologias como transgenia, genômica, proteômica e bioinformática, estão sendo rapidamente incorporadas. A associação dessas tecnologias aos programas de melhoramento convencional de árvores pode acelerar o processo de obtenção de árvores com características específicas da madeira para a indústria de papel e celulose. UDP-glicose pirofosforilase (UGPase, EC 2.7.7.9) é uma enzima chave na produção de UDP-glicose, intermediário na interconversão de carboidratos envolvidos em várias funções metabólicas, como síntese de sacarose e de celulose. No presente trabalho, foi clonado o cDNA que codifica a UGPase. Este cDNA foi sintetizado por meio de RT-PCR utilizando-se mRNA extraído de tubérculo de batata (Solanum 
tuberosum L.). Os primers específicos para a ORF do gene da UGPase foram definidos com base em seqüências conservadas entre genes ortólogos, já disponíveis em bancos de dados. O cDNA foi clonado no vetor pENTR-D TOPO e inserido, por meio de transformação química, em células competentes de Escherichia coli. O DNA plasmidial foi purificado e após seu sequenciamento, a presença de um inserto de 1402 pb foi confirmada. O alinhamento da seqüência deduzida de aminoácidos com outras UGPases revelou alta homologia a UGPases de batata e de outras espécies vegetais. Na sequiência do cDNA clonado foram identificados sítios de $N$-glicosilação, resíduos lisina e motivos conservados que possivelmente estão relacionados tanto com a capacidade de ligação ao substrato, como com a atividade catalítica da enzima. Também foi realizada uma análise de Southern blot para confirmar a presença deste gene no DNA genômico de batata e de eucalipto (Eucalyptus grandis). Posteriormente, o cDNA clonado será utilizado na avaliação do impacto de sua superexpressão na biossíntese de celulose e hemiceluloses e no desenvolvimento de plantas de fumo (Nicotiana tabacum) e de eucalipto. 


\section{CLONING OF cDNA ENCODING POTATO (Solanum tuberosum L.) UDP-GLUCOSE PYROPHOSPHORYLASE}

Author: GUNTA GUTMANIS

Adviser: Prof. Dr. CARLOS ALBERTO LABATE

\section{SUMMARY}

Biotechnology is revolutionazing human activity in several fields. In forestry, new technologies like transgenies, genomics, proteomics and bioinformatics have been quickly consolidated. Assossiating these technologies with conventional forestry breeding will accelerate the process of obtaining new trees with specific wood properties for the paper and pulp industry. UDP-glucose pyrophosphorylase (UGPase, EC 2.7.7.9) is a key enzyme producing UDP-glucose, an important intermediate in carbohydrate interconversion involved in various metabolic processes like sucrose and cellulose synthesis. In this work, it was cloned the cDNA that encodes UGPase. This cDNA was synthetized through RT-PCR using RNA extracted from potato (Solanum tuberosum L.) tuber. The UGPase primers were designed based on the conserved sequences of hortologous genes, already available in public data banks. The cDNA was cloned into pENTR-D TOPO vector and introduced into Escherichia coli competent cells, by chemically transforming. The plasmid DNA was purified and the insert PCR amplified. 
The presence of $1402 \mathrm{bp}$ insert was confirmed after sequencing. The alignment of the derived amino acids sequence with other UGPases revealed high homobgy to UGPases from potato and other plant species. Along the cDNA sequence $N$-glicolisation sites, Lysyl residues and conserved domain were identified, which probably are involved in substrate binding capacity, as well as catalytic ativity of the enzyme. Southern blot analysis was carried to confirm the presence of this gene in potato and eucalypt (Eucalyptus grandis) genomic DNA. The cloned cDNA will be used to evaluate the impact of overexpression on celullose and hemicelluloses biosynthesis and in the tobacco (Nicotiana tabacum) and eucalypt plant development. 


\section{INTRODUÇÃO}

A biossíntese dos polissacarídeos da parede celular é responsável pelo consumo da maior parte do carbono fixado pelas plantas superiores. A celulose é o composto orgânico mais abundante na natureza. Nas árvores, o conteúdo de celulose presente nos vasos lenhosos compreende cerca de 40-50\% do peso seco total, sendo o restante composto por hemiceluloses e lignina.

A importância econômica da celulose para o setor florestal tem despertado grande interesse na alteração da sua biossíntese, utilizando técnicas de biologia molecular. A manipulação do fluxo do carbono para a celulose, por sua vez, depende não só do conhecimento das rotas metabólicas responsáveis pela sua síntese, mas também das rotas que competem por carbono nas várias partes da planta, nos diferentes estádios de desenvolvimento.

Um dos principais substratos utilizados para a síntese dos polissacarídeos da parede celular é a UDP-D-glicose. Entretanto, não está claro quais são as rotas de síntese de UDP-glicose, como também os possíveis intermediários desse processo (Delmer, 1999b; Haigler et al., 2001; Delmer e Haigler, 2002).

A UDP-glicose que serve de matéria prima para a síntese de sacarose e celulose, sendo, portanto, um componente importante na partição do carbono entre os vários compostos. As hemiceluloses em dicotiledôneas são formadas, em grande parte, a partir dos açúcares xilose e glucoronato e, em menor proporção, a partir de glicose e manose (Dalessandro e Northcote, 1977a). 
A enzima que catalisa a interconversão de Dglicose em UDP-glicose é a UDPglicose pirofosforilase (UGPase, EC 2.7.7.9), o que a torna uma enzima chave na síntese de polissacarídeos da parede celular.

Clones de cDNA que codificam UDP-glicose pirofosforilase têm sido isolados a partir de bibliotecas de cDNA obtidas de diversos organismos como, por exemplo, batata (Katsube et al., 1990), fígado bovino (Konishi et al.,1993), fígado humano (Peng \& Chang, 1993), levedura (Daran et al., 1995) e cevada (Eimert et al, 1996), sendo que suas sequiências encontram-se disponíveis em bancos de dados de acesso público, via Internet. A quantidade de informações sobre a seqüência codificadora desta enzima disponíveis nos bancos de dados permite desenhar um par de primers que pode ser usado na amplificação dessa seqüência a partir de DNA genômico ou na síntese de cDNA através da reação de RT-PCR.

O objetivo do presente trabalho foi clonar o cDNA que codifica a enzima UDPglicose pirofosforilase (UGPase, EC 2.7.7.9), que posteriormente será utilizado na avaliação do impacto de sua superexpressão na biossíntese de celulose e hemiceluloses da parede celular e no desenvolvimento de plantas. Primeiramente, serão avaliadas plantas de fumo (Nicotiana tabacum), usadas como sistema modelo para análises preliminares, e em seguida, eucalipto (Eucalyptus grandis), visando melhorar as propriedades da fibra e da polpa que afetam a produção e a qualidade do papel destinado a diferentes usos como, por exemplo, impressão ou embalagens. 


\section{REVISÃO DE LITERATURA}

\subsection{Enzima UDP-glicose pirofosforilase}

O nome oficial da enzima de código EC:2.7.7.9 é UTP--glicose-1-fosfato uridililtransferase e os nomes alternativos são UDP-glicose pirofosforilase (UDPGP ou UGPase), UDP-glicose difosforilase e Glicose-1-fosfato uridililtransferase. A UGPase catalisa a interconversão de MgUTP + alfa-D-glicose 1-fosfato em UDP-glicose + difosfato (http://us.expasy.org/enzyme).

A UGPase já foi purificada de uma variedade de organismos, incluindo bactéria (Hossain et al, 1994), tecido animal (Konishi et al., 1993) e vegetal (Nakano et al., 1989a). Em plantas, a UGPase existe na forma de monômero de aproximadamente 50 kDa (Nakano et al, 1989a) e apresenta-se predominantemente como proteína citosólica solúvel embora haja registros de atividade de UGPase ligada à membrana tanto para tecidos animais como vegetais (Kleczkowski, 1994).

A ampla distribuição desta enzima na natureza deve-se ao seu papel na síntese de numerosos compostos que requerem a UDP-glicose. A UGPase atua nas vias metabólicas de interconversão de pentose e glucoronato, metabolismo da galactose, metabolismo de nucleotídeos de açúcares e metabolismo do amido e sacarose (http://www.genome.ad.jp/ $\mathrm{kegg} / \mathrm{kegg} 2 . \mathrm{hml}$ ), que envolve a biogênese da parede celular.

A atividade da UGPase em tubérculos de batata desperta interesse devido à habilidade desta enzima promover o acúmulo de açúcar reduzido durante a estocagem a baixas temperaturas (Spychalla et al., 1994; Ciereszko et al, 2001a). A enzima também 
está envolvida com o amadurecimento de frutos como a banana (Pua et al, 2000) e tomate (Picton et al, 1993). Em mamíferos, a UDP-glicose é um importante intermediário na interconversão de carboidratos envolvidos em várias funções metabólicas que dependem do tipo de tecido.

\subsection{Biossíntese de componentes da parede celular}

A biossíntese da celulose, bem como dos demais componentes da parede celular, como hemiceluloses, pectina e lignina, depende do fornecimento dos açúcares produzidos pela fotossíntese nos cloroplastos. O carbono fixado pela fotossíntese é exportado do cloroplasto para o citoplasma na forma de uma triose-fosfato (DHAP), iniciando uma série de reações metabólicas cuja direção do fluxo vai depender de vários fatores como estádio de desenvolvimento das folhas, estado fisiológico da planta, condição nutricional, entre outros. Nas folhas jovens, grande parte dos fluxos metabólicos são preferencialmente utilizados para a síntese de lipídeos, via da pentose fosfato (para a síntese de ácidos nucléicos), glicólise (gerando ATP e piruvato), ciclo dos ácidos tricarboxílicos (TCA), síntese de aminoácidos, e a via de oxidação dos açúcares, responsáveis pela síntese dos componentes da parede celular.

Os substratos utilizados para a síntese dos polissacarídeos da parede celular são açúcares tais como: UDP-D-glicose, UDP-D-glucoronato, UDP-D-galactose, UDP-Dxilose e UDP-L-arabinose (Reiter e Vanzin, 2001). Nas bactérias a síntese de celulose parece depender apenas da disponibilidade de UDP-glicose para a formação das cadeias de glucanos. Por outro lado, nas plantas superiores a rota de biossíntese da celulose ainda é questionável (Delmer e Haigler, 2002). Os modelos propostos recentemente apresentam fortes indícios de que o açúcar UDP-glicose também é o provável substrato nas plantas. Uma evidência importante está no fato da enzima celulose sintase se associar a UDPglicose e promover a síntese de celulose in vitro (Delmer 1999a). Entretanto, o que não está claro são as rotas de síntese de UDP-glicose, como também os possíveis intermediários desse processo (Delmer, 1999b; Haigler et al., 2001; Delmer e Haigler, 
2002). Esses trabalhos mostram a existência de uma inter-relação dos vários substratos envolvidos na síntese da celulose e hemiceluloses, de tal forma que os fluxos de carbono para esses dois compostos é altamente regulado.

A importância metabólica da UGPase na formação de UDP-glicose foi demonstrada em linhagens mutantes de Dictyostelium discoideum que tiveram a atividade da UGPase reduzida. A morfogênese de linhagens mutantes foi suspensa em estádios de crescimento que necessitavam a mobilização de estoques de glicogênio em UDP-glicose equivalente ao usado na formação de celulose (Dimond et al, 1976).

As hemiceluloses em dicotiledôneas são formadas, em grande parte, a partir dos açúcares xilose e glucoronato e, em menor proporção, a partir de glicose e manose (Dalessandro e Northcote, 1977a). A biossíntese de UDP-D-xilose é mediada pela enzima UDP-glucoronato descarboxilase (EC 4.1.1.35), a partir de UDP-D-glucoronato (Bar-Peled et al, 2001). O UDP-D-glucoronato pode ser formado por duas vias metabólicas. A primeira consiste da conversão, pela ação da enzima fosfoglucomutase (EC 5.4.2.2), de Dglicose-6-fosfato em D-glicose-1-fosfato, que é convertido em UDPglicose pela enzima UDP-D-glicose pirofosforilase (EC 2.7.7.9). Já a enzima UDPglicose desidrogenase (EC 1.1.1.22) é a responsável pela conversão do açúcar UDP-Dglicose em UDP-D-glucoronato. A segunda via de forma ção do UDP-D-glucoronato corresponde à rota metabólica de oxidação do mio-inositol (Reiter e Vanzin, 2001).

O mio-inositol é formado a partir de glicose-6P, o mesmo precursor de UDPglicose. Esse composto é um precursor importante para uma série de produtos metabólicos, como fosfatos de inositol, fosfoinositídeos, derivados metilados e conjugados de IAA, e ácido glucurônico. A produção do inositol envolve a síntese de mio-inositol-1-fosfato (Ins-1P) a partir de D-glicose-6P, catalisado pela enzima mioinositol-3-fosfato sintase (MIPS, EC 5.5.1.4). O inositol-1P produzido é, em seguida, desfosforilado pela enzima inositol monofosfatase (IMP, EC 3.1.3.25) para liberar mioinositol. Uma vez produzido, o mio-inositol pode seguir várias rotas metabólicas ou ser oxigenado pela enzima mio-inositol oxigenase (EC 1.13.99.1), formando ácido 
glucurônico (Figura 1). Essa reação é irreversível e o produto formado pode ser diretamente transferido para a síntese da parede celular ou ser fosforilado pela enzima glucoronoquinase (EC 2.7.1.43) e em seguida, desfosforilado pela enzima glucoronato 1fosfato uridiltransferase (EC 2.7.7.44) (Loewus et al., 1962; Loewus \& Murthy, 2000).

Até o momento não é conhecida qual das rotas de síntese do UDP-glucoronato é a mais importante nas plantas. Existem evidências de que as duas vias metabólicas coexistem, variando a importância de cada uma durante o desenvolvimento da planta (Roberts e Loewus, 1973; Dalessandro e Northcote 1977a, 1977b; Witt, 1992).

Vários trabalhos têm demonstrado que a produção de UDP-glucoronato pode ser limitante para o suprimento de precursores da parede celular em desenvolvimento. Portanto, o que se acredita é que a enzima UDP-glicose desidrogenase (EC 1.1.1.22) é um fator regulador dessa via metabólica (Amino et al 1985, Robertson et al 1995). 


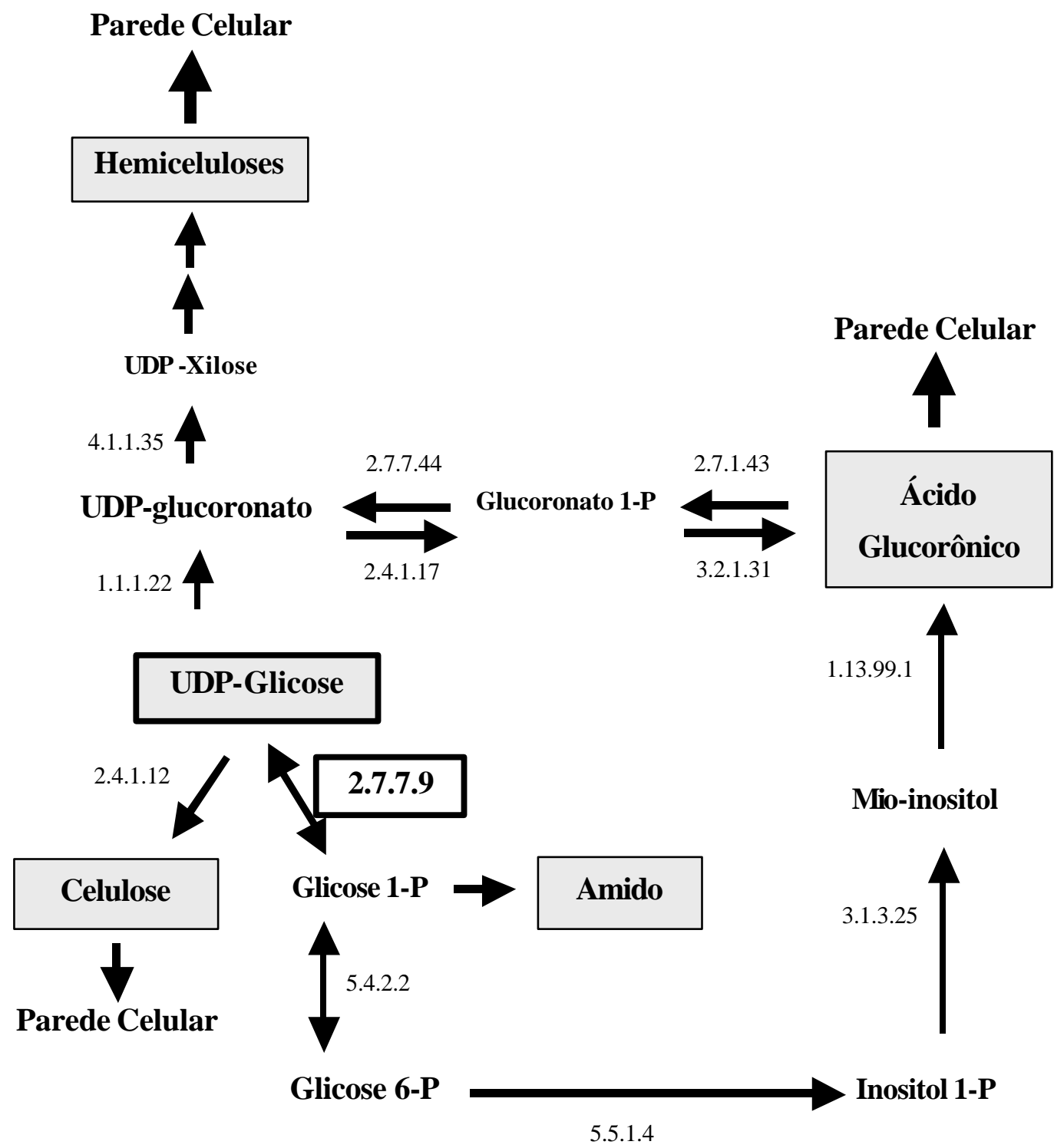

Figura 1- Representação esquemática da formação das hemiceluloses, celulose e ácido glucorônico a partir do açúcar glicose 6P e da via de oxidação do mio-inositol. 5.5.1.4, mio-inositol-1-fosfato sintase (MIPS); 3.1.3.25, mio-inositol monofosfatase (IMP); 1.13.99.1, mio-inositol oxigenase; 3.2.1.31, $\beta$-glucuronidase; 2.7.1.43, glucoronoquinase; 2.4.1.17, glucoronosil-transferase; 2.7.7.44, glucoronato 1fosfato uridililtransferase; 5.4.2.2, fosfoglucomutase; 2.7.7.9, UDPglicose pirofosforilase; 1.1.1.22, UDP-glicose desidrogenase, 4.1.1.35, UDP-glucoronato descarboxilase; 2.4.1.12, celulose sintase 


\subsection{Métodos de clonagem}

O termo clonagem significa a produção de um segmento de DNA, grupo de células ou de indivíduos geneticamente idênticos, por meio de reprodução assexuada, a partir de um ancestral comum. Quando aplicado ao DNA, a clonagem é entendida como a inserção de uma seqüência de DNA em uma célula de tal modo que o DNA seja replicado e conservado.

O isolamento e clonagem de um gene individual a partir do genoma tornourse possível com o advento da tecnologia do DNA recombinante. O procedimento básico de clonagem consiste em extrair e cortar o DNA do genoma doador em fragmentos contendo de um a vários genes e permitir que estes fragmentos sejam inseridos individualmente em pequenas moléculas de DNA de replicação autônoma, chamadas de vetores, que podem ser plasmídeos, fagos, cosmídeos ou cromossomos artificiais de bactérias. O DNA recombinante (molécula vetora e sua inserção) é introduzido em células bacterianas por meio de transformação. Uma vez na célula hospedeira, o vetor irá se replicar, independentemente do cromossomo bacteriano e, com ele, irá replicar o fragmento exógeno resultando em um clone molecular do fragmento de DNA inserido. Após muitos ciclos de multiplicação celular, uma única célula transformada com um único vetor recombinante origina uma colônia com milhões de células, todas portadoras do mesmo vetor recombinante (Sambrook et al, 1989; Foster \& Twell, 1996). Geralmente, os vetores possuem genes que conferem resistência a antibiótico o que permite a seleção das células transformadas. Uma coleção de clones de DNA é chamada de biblioteca de DNA que, dependendo da fonte de DNA, pode ser uma biblioteca genômica ou uma biblioteca de cDNA. O uso de cDNA apresenta como vantagem o menor tamanho devido à ausência de íntrons em sua sequiência.

Em uma biblioteca, a maioria das colônias será portadora de diferentes inserções clonadas. O clone contendo o gene de interesse, pode ser detectado usando-se uma sonda específica para o DNA ou seu produto protéico, ou verificando-se sua capacidade de 
transformar um mutante nulo. $\mathrm{O}$ vetor do clone selecionado pode ser extraído e seqüenciado e o gene usado na pesquisa de sua função celular.

Uma maneira alternativa para a clonagem, sem a necessidade de construção de bibliotecas e de sondagens, pode ser por meio da reação em cadeia da polimerase (PCR) (Innis \& Gelfand, 1990), utilizando dados de genes já clonados. Desde que as sequiências que delimitam sua ORF sejam conhecidas, um par de primers (oligonucleotídeos iniciadores) pode ser quimicamente sintetizado e usado para amplificar esse fragmento, a partir do DNA genômico ou do cDNA, em quantidade suficiente a ser clonada diretamente em um vetor (Scharf et al., 1986; Scharf, 1990).

\subsection{Clonagem do gene da UGPase}

A seqüência de nucleotídeos de um único cDNA completo que codifica a UGPase em plantas foi clonada pela primeira vez de tubérculos de batata por Katsube et al (1990) que utilizaram uma biblioteca de cDNA previamente elaborada por Nakano et al. (1989b) e sondas de oligonucleotídeos sintetizados com base na sequiência parcial de aminoácidos da enzima. A seqüência de DNA foi determinada pelo método de Sanger. Uma ORF de 1431 pb de início no códon de iniciação ATG e término no códon nonsense TAG, foi identificada como a unidade de tradução da UGPase. Com base na seqüência deduzida de aminoácidos (477 resíduos) o peso molecular da enzima foi calculado em 51.783 Da.

Spychalla et al. (1994) utilizou uma biblioteca de expressão de cDNA de tubérculos de batata em fagos, e sonda anti-UGPase policlonal de Sowokinos et al (1993). O maior clone isolado foi subclonado em pUC119 e seqüenciado em ambas as direções. O UGPase-cDNA encontrado apresentou 1701 pb e uma ORF de 1431 pb, altamente homólogo ao descrito por Katsube et al. (1990). As duas ORFs diferiram em apenas 26 bases, o que resultou em cinco diferenças na seqüência deduzida de aminoácidos. 
A organização do gene que codifica a UGPase em batata (cv. Lemhi) foi determinada por Borovkov et al. (1997) a partir de biblioteca genômica ëFIXII. O gene clonado consiste de uma região estrutural de $6,6 \mathrm{~kb}$ e uma regulatória de $1 \mathrm{~kb}$. A região estrutural contém 20 éxons e 19 íntrons. Foram identificados os sítios putativos de poliadenilação, de início de ranscrição e TATA-box. A região regulatória contém um enhancer, supressor e regiões responsáveis por expressão tecido-específica da UGPase. A seqüência codante, com exceção de três bases, é idêntica ao cDNA de UGPase previamente clonado do cv. DanshakurImo. (Katsube et al., 1990).

A comparação de dois clones de cDNA de UGPase de batata (Katsube et al, 1990; Spychalla et al., 1994) e um clone genômico (Borovkov et al., 1997) revelou apenas poucas diferenças na região codante. Segundo o último autor, as seqüências são formas alélicas diferentes em diferentes cultivares, especialmente se a UGPase se apresenta na forma de homodímero, como proposto por Sowokinos et al. (1993). 


\section{MATERIAL E MÉTODOS}

\subsection{Pesquisa em bancos de dados}

O primeiro passo do processo de clonagem do gene codificador da enzima UGPase foi a realização de uma busca de genes ortólogos (homólogos que apresentam a mesma função em organismos diferentes) no banco de dados do NCBI e KEGG, a partir do código enzimático EC 2.7.7.9.

\section{$\underline{\mathrm{NCBI}}$}

NCBI National Center for Biotechnology Information) é um centro de informação biotecnológica, criado pelo governo americano em 1988, que gera bancos de dados de domínio público com acesso via Internet através da página eletrônica http://www.ncbi.nlm.nih.gov/, desenvolve programas para a análise de dados, como BLAST e ORF Finder, e mantém intercâmbio de dados com outros centros de pesquisa internacionais através de atualizações diárias, o que faz com que esses bancos estejam em constante crescimento.

Algumas das opções de BLAST (Basic Local Alignment Search Tool) utilizadas foram:

a. BlastN: confronta a seqüência de nucleotídeos a ser analisada contra as seqüências de nucleotídeos disponíveis na base de dados do NCBI.

b. BlastX: confronta a sequiência de nucleotídeos a ser analisada contra as sequiências de proteínas disponíveis na base de dados do NCBI. 
c. Blast 2 Sequences: faz a análise comparativa de alinhamento múltiplo de duas ou mais seqüências de nucleotídeos ou proteínas.

\section{$\underline{\text { KEGG }}$}

A Enciclopédia de Genes e Genomas de Kyoto - KEGG (Kanehisha et al, 2002) através da página eletrônica http://www.genome.ad.jp/kegg/kegg2.html, apresenta um sistema de busca com diversas alternativas. Permite a procura de vias metabólicas e regulatórias a partir de nomes de vias, produtos ou códigos (número $\mathrm{EC}$ ), ou ainda, permite a comparação de uma seqüência ao seu banco de dados.

\section{CLUSTAL W}

A similaridade entre diferentes sequiências de aminoácidos e entre suas respectivas seqüências de nucleotídeos, obtidas no NCBI ou KEGG, foi examinada através do programa Clustal W (1.82). O programa Clustal W Multiple Sequence Alignments (http://www.ebi.ac.uk/clustalw/) produz alinhamento biologicamente significativo de diversas seqüências de DNA ou de proteínas, calcula o melhor pareamento para as seqüências escolhidas e as alinha de forma que as similaridades e diferenças possam ser observadas (Thompson et al, 1994).

Alguns termos utilizados na busca em bancos de dados e em seus programas são:

a. GI number (GenInfo Identifier): identificador único para cada seqüência de nucleotídeos, independente de atualizações, representado por um número inteiro simples. Se uma sequiência difere da outra por apenas um par de bases, as duas possuirão diferentes gi(s), apesar de possuírem, por exemplo, o mesmo número de acesso.

b. Accession: número de acesso direto de uma seqüência de nucleotídeos ao GenBank. As letras indicam em qual centro a sequiência foi submetida. $\mathrm{O}$ complemento, separado do número de acesso por um ponto, indica qual é a versão (atualização).

c. Protein id: código similar ao número de acesso dado para sequiências de proteínas. 
d. formato FASTA: é o modelo padrão usado na comparação de uma determinada sequiência com sequiências do banco de dados através do alinhamento da mesma. A primeira linha, indicada pelo sina $1>$ (maior que), é a identificação da seqüência. $\mathrm{O}$ texto é apresentado sem formatação (ou courier new 10), com quebra de linhas, contendo no máximo 80 caracteres por linha e obedecendo ao código padrão IUPAC/ IUB (Anexo A e B) de representação de aminoácidos e ácidos nucléicos.

e. E-value (Expect value): este número indica a probabilidade de que alinhamentos com esta qualidade possam ser obtidos ao acaso em um banco de dados no mesmo tamanho do utilizado na pesquisa. O número indicado corresponde à potência de 10 . Por exemplo, 5e-23 significa uma probabilidade de $5 \times 10^{-23}$. Quanto mais próximo de zero for o $E$-value, mais significativo é o alinhamento entre as seqüências. $\mathrm{O}$ cálculo do $E$ value leva em consideração o comprimento da seqüência em questão, portanto, para seqüências curtas, como no caso de primers, o valor de E-value pode ser alto para seqüências virtualmente idênticas.

f. Bit Score : é uma medida de similaridade entre uma consulta e o resultado da busca em uma base de dados. Essa medida é citada próxima ao E-value. O Bit Score é inversamente proporcional aos valores de E-value.

\subsection{Definição dos primers para a ORF}

Os primers que flanqueiam a ORF do gene que codifica a UGPase, utilizados na reação de RT-PCR, foram definidos com auxílio do programa Clustal $\mathrm{W}$, através do alinhamento de sequiências de 21 nucleotídeos das extremidades 5' e 3' de genes ortólogos, considerando a necessidade de se usar primers degenerados (Lee \& Caskey, 1990). A clonagem do gene que codifica a UGPase foi feita com o auxílio do Sistema Gateway $^{\mathrm{TM}}$ de clonagem da Invitrogen (Karimi, et al, 2002). Desta forma, a sequiência de direcionamento CACC do sistema Directional $\mathrm{TOPO}^{\circledR}$ foi adicionada à extremidade 5 , do Forward Primer. Com a ajuda da página eletrônica http://wwwgenome.wi.mit.edu/cgi-bin/primer/primer3_www.cgi verificourse a viabilidade destes 
primers relacionada à porcentagem de $\mathrm{C} / \mathrm{G}$, temperatura de anelamento $(\mathrm{Tm})$ e ausência de auto-complementariedade. Estes primers foram submetidos à confirmação de identidade com auxílio do programa BlastN - opção Search for Short Nearly Exact Matches, no banco de dados do NCBI e sintetizados pela Invitrogen.

\subsection{Extração de RNA total}

Para extração de RNA total utilizoutse o método de Salzman et al. (1999), a partir de tubérculo de batata, conforme descrição abaixo.

\subsubsection{Preparo de material livre de RNase}

Para evitar a degradação do RNA por RNases, todas as soluções e reagentes foram preparados com água previamente tratada com DEPC (dietilpirocarbonato) na concentração de $1 \%$, por 16 horas a $37^{\circ} \mathrm{C}$, seguida de autoclavagem $\left(120^{\circ} \mathrm{C}, 1 \mathrm{~atm}, 20\right.$ minutos). Com a mesma finalidade, todo material plástico utilizado foi tratado através de uma seqüência de lavagens com SDS $2 \%$ por 2 horas a $70^{\circ} \mathrm{C}$, álcool comercial por 20 minutos, e $\mathrm{H}_{2} \mathrm{O}_{2} 3 \%$ por mais 20 minutos. Dois enxágü es finais com $\mathrm{H}_{2} \mathrm{O}$ DEPC $0,01 \%$, por 20 minutos, foram feitos antes da autoclavagem. A vidraria e porcelanas utilizadas foram esterilizadas a seco, a $200^{\circ} \mathrm{C}$, por 6 horas. A cuba de eletroforese e seus componentes foram lavados com SDS 0,1\% e enxaguados com água livre de RNase.

\subsubsection{Extração de RNA}

O tecido vegetal ( $2 \mathrm{~g}$ de tubérculo de batata) foi macerado em nitrogênio líquido com auxílio de almofariz e pistilo. O material macerado foi transferido a um tubo de centrífuga (50 ml) contendo $10 \mathrm{ml}$ de tampão de extração de RNA (Anexo C), seguido de agitação em vórtex, por 1 minuto. A esse material adicionoutse igual volume de CIA $(24: 1 \mathrm{v} / \mathrm{v})$. Esse foi, então, agitado a $200 \mathrm{rpm}, 25^{\circ} \mathrm{C}$, por 20 minutos, antes da 
centrifugação a $16.000 \times \mathrm{g}$, por 10 minutos, a $4^{\circ} \mathrm{C}$. A fase superior foi cuidadosamente transferida para novo tubo. Essa extração com CIA foi repetida mais duas vezes para a remoção completa do material de interfase. Ao sobrenadante final, já em novo tubo, adicionou-se 2 volumes do homogenato de etanol absoluto e 0,1 volume de homogenato de $\mathrm{NaCl} 5 \mathrm{M}$, para precipitação por 16 horas, a $-20^{\circ} \mathrm{C}$.

Após nova centrifugação a $16.000 \times \mathrm{g}$, por 10 minutos, a $4^{\circ} \mathrm{C}$, o precipitado foi ressuspendido em $10 \mathrm{ml}$ de água tratada com DEPC, seguido de centrifugação por 5 minutos a $20.000 \times g$. O sobrenadante foi transferido para novo tubo, ao qual adicionour se $10 \mathrm{ml}$ de fenol tamponado $(\mathrm{pH}=8,0)$ : clorofórmio: álcool isoamílico na proporção 25:24:1. Após agitação por 10 minutos, à temperatura ambiente, e depois centrifugado a $13.000 \times \mathrm{g}$, por 10 minutos, à temperatura ambiente, a fase superior foi transferida cuidadosamente para novo tubo. A etapa anterior foi repetida mais uma vez. Ao sobrenadante adicionou-se 2 volumes de etanol absoluto e 0,1 volume de $\mathrm{NaCl} 5 \mathrm{M}$, seguida de precipitação, por 16 horas, a $4^{\circ} \mathrm{C}$.

Depois da centrifugação a $16.000 \times \mathrm{g}$, por 15 minutos, a $4^{\circ} \mathrm{C}$, o precipitado foi ressuspendido em $500 \mu$ l água milliQ tratada com DEPC. Após centrifugação adicional, o volume da amostra foi elevado para $1 \mathrm{ml}$ com água milliQ tratada com DEPC. A esse se adicionou $333 \mu \mathrm{l}$ de $\mathrm{LiCl} 8 \mathrm{M}$. A precipitação foi feita a $4^{\circ} \mathrm{C}$, por pelo menos 3 horas, antes da centrifugação a $12.000 \times \mathrm{g}$, por 20 minutos, a $4^{\circ} \mathrm{C}$. O precipitado foi lavado com $400 \mu \mathrm{l}$ de etanol $80 \%$, preparado em água $\mathrm{DEPC}$, centrifugado a $12.000 \times \mathrm{g}, 4^{\circ} \mathrm{C}$, por 10 minutos e seco sobre papel absorvente, antes de ser ressuspendido em $50 \mu 1$ de água tratada com DEPC.

\subsubsection{Quantificação de RNA}

A quantificação das amostras de RNA foi realizada por espectrofotometria, sendo a concentração calculada, para uma cubeta de $10 \mathrm{~mm}$, através da fórmula: 


$$
[\mathrm{RNA}]=\frac{\mathrm{A}_{260} \times \mathrm{Fc} \times \mathrm{Fd}}{1000}
$$

onde: $\mathbf{A}_{260}$ é a absorbância da amostra sob o comprimento de onda de $260 \mathrm{~nm}$; Fc é o fator de conversão no qual 1 unidade de absorbância a $260 \mathrm{~nm}$ corresponde a $40 \mu \mathrm{g}$ RNA/ml (Sambroock et al., 1989); Fd corresponde ao fator de diluição da amostra de leitura, no caso, 200 (4 $\mu 1$ de amostra em $800 \mu$ l água DEPC); o resultado da multiplicação é dividido por mil para obter-se a concentração em $\mu \mathrm{g} / \mu 1$.

A qualidade do RNA foi analisada com base na rehção $\mathrm{A}_{260} / \mathrm{A}_{280}$, onde valores maiores que 1,6 indicam boa qualidade do RNA extraído. A qualidade também foi observada após desnaturação, através de eletroforese em gel de 1,5\% agarose em tampão TAE 1 X (Anexo D) (Sambrook et al, 1989).

\subsection{Purificação de mR NA a partir de RNA total}

O RNA mensageiro (mRNA) foi purificado a partir do RNA total utilizando-se o kit Dynabeads ${ }^{\circledR}$ mRNA Purification (Dynal), seguindo as recomendações do fabricante. $\mathrm{O}$ uso desse kit baseia-se no pareamento de bases entre resíduos poli A na extremidade 3' da maioria dos mRNA e resíduos oligo dT covalentemente ligados à superfície dos Dynabeads Oligo $(\mathrm{dT})_{25}$. Outros tipos de RNA desprovidos de cauda poli A não hibridizam aos Dynabeads Oligo $(\mathrm{dT})_{25}$ e são prontamente eliminados.

Ao RNA total, numa diluição de $80 \mu \mathrm{g}$ em $100 \mu \mathrm{l}$ de água milliQ tratada com DEPC, acrescentou-se $100 \mu \mathrm{l}$ de tampão de ligação (Binding Buffer) (Anexo E). A amostra foi aquecida a $65^{\circ} \mathrm{C}$ por 2 minutos para que as estruturas secundárias fossem rompidas.

Enquanto isso, $200 \mu \mathrm{l}(1 \mathrm{mg})$ de Dynabeads Oligo $(\mathrm{dT})_{25}$ foram transferidos do estoque para um tubo eppendorf de $1,5 \mathrm{ml}$ de capacidade. Os Oligo $(\mathrm{dT})_{25}$ foram lavados 
uma vez com auxílio do Dynal $\mathrm{MPC}^{\circledR}-\mathrm{S}$ (concentrador magnético de partículas). Essa lavagem é feita removendo-se o tubo do magneto, ressuspendendo os Oligo $(\mathrm{dT})_{25} \mathrm{em}$ $100 \mu 1$ de tampão de ligação e recolocando o tubo no magneto. Depois de 30 segundos, o sobrenadante é pipetado e o tubo, contendo os Oligo (dT) 25 limpos, removido do magneto.

Aos Oligo (dT) ${ }_{25}$ adicionourse $100 \mu 1$ do tampão de ligação e 80 ng de RNA total. A homogeneização foi feita por rotação, por 5 minutos, à temperatura ambiente, no mixer que acompanha o kit.

Em seguida, a amostra homogeneizada foi colocada no magneto e depois de 30 segundos o sobrenadante foi removido. $\mathrm{O}$ tubo foi retirado do magneto e lavado duas vezes com $200 \mu \mathrm{l}$ de tampão de lavagem B (Washing Buffer B) (Anexo F), com auxílio do MPC, da mesma forma como descrito acima, removendo-se completamente o sobrenadante entre cada lavagem.

Para a eluição do mRNA adicionoutse $20 \mu \mathrm{l}$ de Tris- $\mathrm{HCl} 10 \mathrm{mM}$ ao precipitado, seguido de aquecimento $\left(65^{\circ} \mathrm{C}\right)$ por 2 minutos. Após o aquecimento, o tubo foi colocado imediatamente no magneto. O mRNA eluído foi transferido para um tubo novo livre de RNase. A quantidade de mRNA purificado foi verificada por meio de espectrofotometria $\left(\mathrm{A}_{260 \mathrm{~nm}}\right.$ e $\left.\mathrm{A}_{280 \mathrm{~nm}}\right)$ e a qualidade por meio de eletroforese em gel de $1 \%$ agarose (Sambrook et al, 1989).

\subsection{Reação de RT-PCR}

A reação de RT-PCR (síntese de cDNA sobre um molde de mRNA realizada pela enzima transcriptase reversa, seguida de amplificação por meio de PCR, reação em cadeia da polimerase) foi realizada utilizando-se amostra de mRNA extraído da batata e primers forward e reverse específicos para a UGPase, com auxílio do kit Super Script ${ }^{\mathrm{TM}}$ One-step RT-PCR with Platinum ${ }^{\circledR}$ Taq (Invitrogen), segundo protocolo do fabricante. 
Para cada reação adicionoutse $25 \mu \mathrm{l}$ de Mix de Reação (tampão contendo 0,4 mM de cada dNTP e 2,4 mM de $\mathrm{MgSO}_{4}$ ) fornecida pelo kit, $20 \mu \mathrm{lmRNA}, 1 \mu 1$ de cada primer $10 \mu \mathrm{M}, 1 \mu \mathrm{RT} /$ Platinum ${ }^{\circledR}$ Taq e água MilliQ estéril em q.s.p. $50 \mu \mathrm{l}$.

O programa utilizado no termociclador para a reação de amplificação foi: $50^{\circ} \mathrm{C}$ por 30 minutos (síntese de cDNA), $94^{\circ} \mathrm{C}$ por 2 minutos (pré-desnaturação), 38 ciclos de $94^{\circ} \mathrm{C}$ por 15 segundos (desnaturação), $65^{\circ} \mathrm{C}$ por 30 segundos (anelamento) e $72^{\circ} \mathrm{C}$ por 1,5 minuto (alongamento), seguidos de uma extensão final por 5 minutos, a $72^{\circ} \mathrm{C}$.

O produto de amplificação obtido da reação de RT-PCR, utilizando-se o mRNA de batata e os primers específicos para a UGPase, corresponde a $1.434 \mathrm{pb}$, equivalente a 477 aminoácidos. A identificação desse foi feita por meio de eletroforese em gel de $1 \%$ agarose em tampão TBE 0,5 X (Anexo G), submetido a corrente de $75 \mathrm{~V}$ por 60 minutos, tendo como marcador de peso molecular 1kb DNA Ladder (Invitrogen), todos acrescidos de tampão de amostra (Dye IV) (Anexo H) (Sambrook et al, 1989). As bandas foram visualizadas por meio de coloração com brometo de etídio $(0,01 \mathrm{ng} / \mu \mathrm{l})$ sobre luz ultravioleta.

\subsection{Clonagem no vetor TOPO}

O produto de amplificação da reação de RT-PCR anterior foi clonado no vetor pENTR TOPO ${ }^{\circledR}$ (Figuras 2 e 3 ) utilizando-se o kit pENTR Directional TOPO ${ }^{\circledR}$ Cloning (Invitrogen). Este kit permite a clonagem de produtos de reação de PCR sem extremidades coesivas no vetor do Sistema Gateway ${ }^{\mathrm{TM}}$ onde uma recombinação sítioespecífico possibilita a clonagem do inserto na orientação correta com eficiência igual ou superior a $90 \%$.

O vetor $\mathrm{pENTR/D-} \mathrm{TOPO}{ }^{\circledR}$ (2.580 nucleotídeos) é composto de:

- $\quad r r n \mathrm{~B}$ T2 seqüência de terminação de transcrição: bases 268-295

- $\quad r r n \mathrm{~B}$ T1 sequiência de terminação de transcrição: bases 427-470 
- sítio primer M13 forward (-20): bases 537-552

- $\quad$ att $\mathrm{L} 1$ (fita complementar): bases 569-668

- sítio específico único da enzima de restrição $\operatorname{Not~I~(5'~...GC`GGCCGC....3’)~}$

- $\quad$ sítio 1 de reconhecimento TOPO ${ }^{\circledR}$ : bases 680-684

- seqüência de sobreposição (overhang): bases 685-688

- $\quad$ sítio 2 de reconhecimento TOPO $^{\circledR}$ : bases 689-693

- sítio específico único da enzima de restrição AscI (5' ...GG^CGCGCC....3’)

- $\quad a t t \mathrm{~L} 2$ (permite clonagem no vetor de destino Gateway ${ }^{\mathrm{TM}}$ ): bases 705-804

- sítio primer M13 reverse: bases 845-861

- gene de resistência à canamicina para seleção em E. coli: bases 974-1783

- $\quad$ origem de replicação (ori) pUC: bases 1904-2577

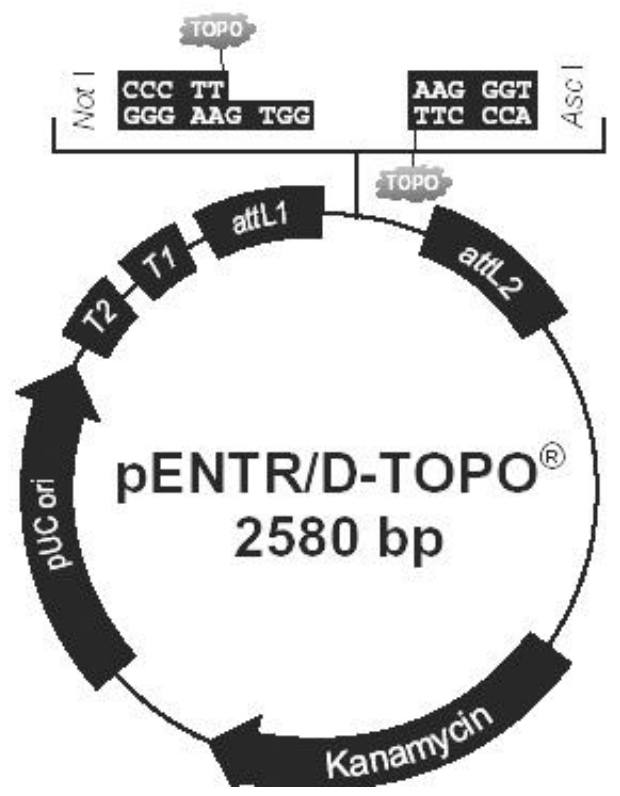

Figura 2- Representação esquemática da construção do vetor pENTR-D TOPO ${ }^{\circledR}$ com a indicação do sítio de clonagem delimitado por sítios de restrição únicos. $\mathrm{O}$ gene quimérico foi inserido entre os sítios de reconhecimento TOPO 


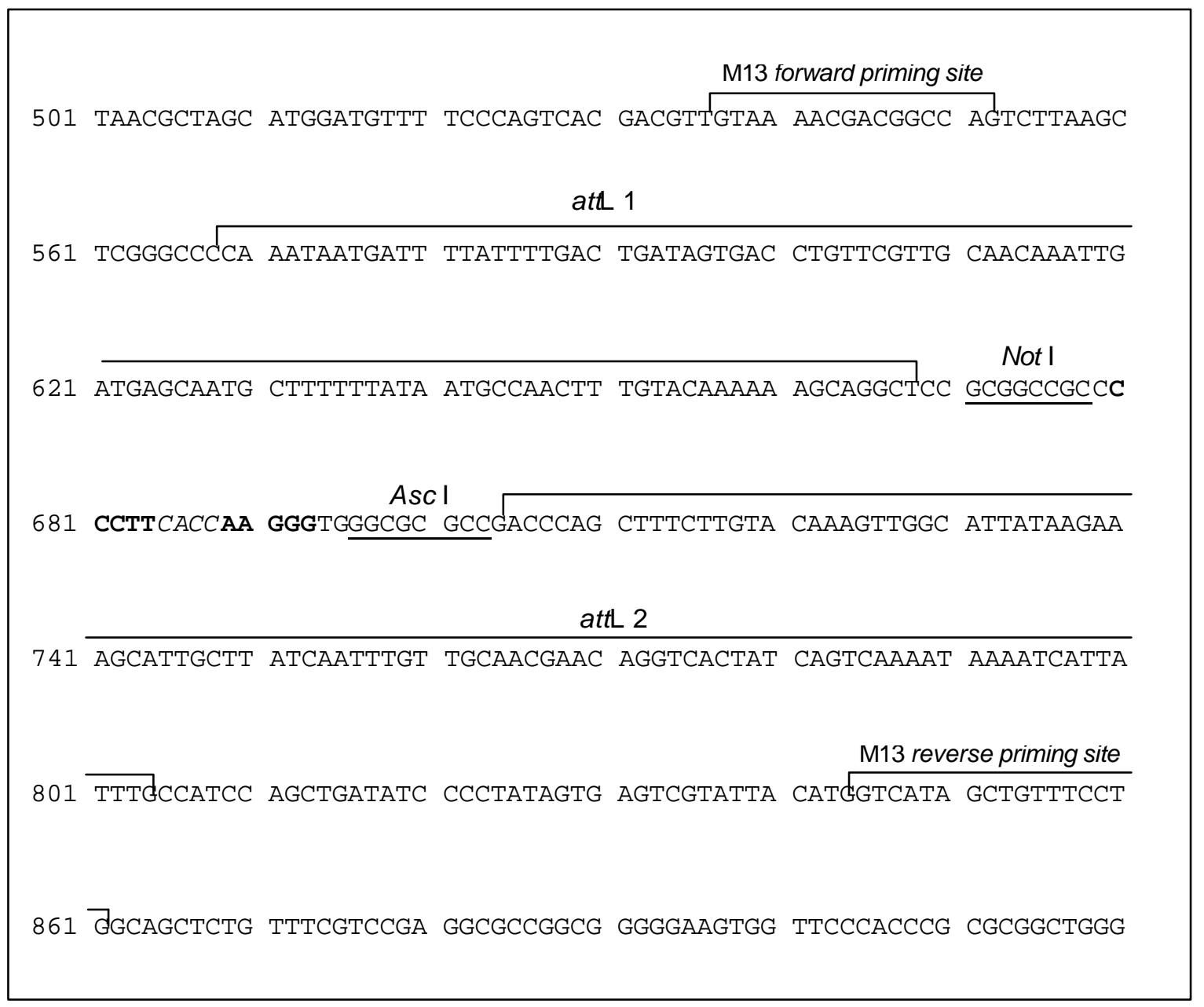

Figura 3- Seqüência de DNA do vetor pENTR-D TOPO compreendida entre os sítios de anelamento dos primers universais M13 forward e reverse. A bases em negrito correspondem aos sítios 1 e 2 de reconhecimento TOPO, e as em itálico à sequiência de sobreposição. Estão indicados os sítios específicos únicos das enzimas de restrição $A s c \mathrm{I}$ e NotI, e as seqüências para recombinação $a t t \mathrm{~L} 1$ e $a t t \mathrm{~L} 2$ 


\subsection{Transformação química de células competentes de $E$. coli}

$\mathrm{O}$ vetor pENTR $\mathrm{TOPO}^{\circledR}$ recombinante foi inserido em células de E. coli One Shot ${ }^{\circledR}$ TOP10 quimicamente competentes (Invitrogen), via transformação química. A mistura de $3 \mu 1$ da reação TOPO Cloning com $25 \mu 1$ de E. coli foi incubada em gelo por 5 minutos seguido de choque térmico a $42^{\circ} \mathrm{C}$ por 30 segundos, retornando ao gelo por mais 5 minutos. Às células recombinantes acrescentourse $250 \mu \mathrm{l}$ de meio de cultura SOC (Invitrogen) (Anexo J). Essas foram então incubadas a $37^{\circ} \mathrm{C}$, em agitador orbital (150 rpm), por 1 hora, antes de serem plaqueadas em meio LB sólido (Anexo K) seletivo, ou seja, acrescido de $50 \mu \mathrm{g} / \mathrm{ml}$ de canamicina. Os transformantes foram visualizados após um período de incubação de 16 horas, a $37^{\circ} \mathrm{C}$.

\subsection{Análise por PCR das colônias transformantes}

A análise de colônias transformantes foi realizada por meio de reação de PCR, utilizando-se um inóculo de cada colônia resistente ao meio seletivo, juntamente com os primers correspondentes à UGPase e reagentes Taq Gen da Biosystems, conforme Anexo I. O inóculo da colônia foi adicionado à reação de PCR, com auxílio de um palito estéril, sob fluxo laminar. Uma incubação a $94^{\circ} \mathrm{C}$, por 10 minutos, foi programada inicialmente no termociclador a fim de lisar as células e inativar as nucleases. A amplificação propriamente dita foi obtida com 35 ciclos de 45 segundos a $94^{\circ} \mathrm{C}$ (desnaturação), 1,5 minuto a $55^{\circ} \mathrm{C}$ (anelamento dos primers) e 2 minutos a $72^{\circ} \mathrm{C}$ (polimerização da fita complementar ao molde). O produto de PCR (10 $\mu$ l de cada reação) foi submetido à eletroforese em gel de $1 \%$ de agarose e as bandas visualizadas por meio de coloração com brometo de etídio $(0,01 \mathrm{ng} / \mu \mathrm{l})$ sobre luz ultravioleta (Sambrook et al, 1989). 


\subsection{Extração de DNA plasmidial}

Para confirmar a autenticidade desses clones recombinantes, extraitrse o DNA plasmidial da colônia transformada utilizando-se Plasmid Mini Kit da QIAGEN. Uma colônia contendo o produto de amplificação referente ao gene de interesse foi utilizada como inóculo em $10 \mathrm{ml}$ de meio LB líquido (Anexo K) suplementado com $50 \mu \mathrm{g} / \mathrm{ml}$ de canamicina sendo mantida em agitador orbital a $200 \mathrm{rpm}$, a $37^{\circ} \mathrm{C}$, por 16 horas. Em seguida, uma fração (3 ml) foi sedimentada por meio de centrifugação a $3.500 \times \mathrm{g}$, a $4{ }^{\circ} \mathrm{C}$, por 10 minutos. O sobrenadante foi removido e o precipitado bacteriano foi então utilizado para a extração de DNA plasmidial.

O protocolo de purificação do kit baseia-se na técnica modificada de lise alcalina pela adição dos tampões P1, P2 e P3 (Anexos L, M e N), seguida pela ligação do DNA plasmidial à resina de troca-aniônica Qiagen previamente equilibrada com tampão QBT (Anexo O). RNA, proteínas, pigmentos e impurezas de baixo peso molecular são removidos por meio de 4 lavagens com tampão QC (Anexo P) de média salinidade. $\mathrm{O}$ DNA é eluído pelo tampão QF (Anexo Q) de alta salinidade e, então, concentrado e desalinizado por meio de precipitação em isopropanol e lavagem com etanol $70 \%$. O DNA resultante foi diluído em água para posterior seqüenciamento. A quantificação foi feita através de eletroforese em gel de $1 \%$ de agarose, tendo 50 e 100 ng de DNA ë (Promega) como padrão de peso molecular. As bandas foram visualizadas por meio de coloração com brometo de etídio $(0,01 \mathrm{ng} / \mu \mathrm{l})$ sobre luz ultravioleta.

\subsection{Seqüenciamento de DNA plasmidial}

O seqüenciamento foi realizado em colaboração com o Laboratório de Biologia Molecular - CENA/ USP, através do “ABI PRISM 3100 genetic analyser” que consiste de uma plataforma automatizada com capacidade de analisar 16 amostras simultaneamente por eletroforese capilar. Antes de serem transferidas para o sequienciador 3100 , as amostras de DNA foram desnaturadas a $95^{\circ} \mathrm{C}$ por 5 minutos em termociclador GeneAmp 9700 e mantidas em gelo por 2 minutos. 
As amostras foram seqüenciadas com o ABI PRISM BigDye ${ }^{\mathrm{TM}}$ Terminator Cycle Sequencing Ready Reaction Kit (Applied Biosystems). Foram utilizados $2 \mu \mathrm{l}$ de TRR Mix, 3,2 pmoles de primer M13 forward (5'-GTAAAACGACGGCCAG-3') ou reverse (5'-CAGGAAACAGCTATGAC-3'), $6 \mu \mathrm{l}$ de buffer 2,5X (200 mM Tris-HCL pH 9,0 e 5 $\mathrm{mM} \mathrm{MgCh}$ ) e $200 \mathrm{ng}$ de DNA, em um volume final de $20 \mu$ l. O programa apresentou 40 ciclos de $96^{\circ} \mathrm{C}$ por 10 segundos, $52^{\circ} \mathrm{C}$ por 20 segundos e $60^{\circ} \mathrm{C}$ por 4 minutos.

\subsection{Análise do seqüienciamento do plasmídeo}

A seqüência de nucleotídeos obtida do seqüenciamento do plasmídeo foi comparada com dados genéticos no GenBank por meio do programa BlastX (Altschul et al, 1997), que permite a procura de uma proteína a partir de uma sequiência de nucleotídeos, disponível no endereço http://www.ncbi.nlm.nih.gov/. A busca resulta em uma representação gráfica onde a linha vermelha que se estende por toda a parte superior representa a própria seqüência examinada, denominada query. As seqüências resultantes da busca são ordenadas por valores decrescentes de Bit Score. À medida que o vabr do Score decai (e o correspondente E-value aumenta), menor é o grau de homologia.

O resultado do seqüenciamento também foi confrontado com a seqüência da ORF da UGPase de batata através do programa Blast 2 Sequences, disponível no mesmo site.

\subsection{Verificação de domínios conservados}

As proteínas podem conter de um a vários domínios, cada um com uma função e origem evolutiva diferentes. A seqüência de nucleotídeos obtida pôde ser comparada à base de dados CDD (Conserved Domain Database) por meio dos web sites http://www.ncbi.nlm.nih.gov/Structure/cdd/cdd.shtml ou http://pfam.wustl.edu/ - Protein search. 
O programa Pfam (Bateman et al., 2002) versão 10.0 contém modelos para 6.190 famílias de proteínas, baseados em seqüências de proteínas dos bancos de dados Swissprot e SP-TrEMBL.

O retorno da consulta pode conter símbolos que indicam se o Score é bom quando comparado a outros membros da família Pfam. O símbolo !! sinaliza um alinhamento altamente significativo e, portanto, indica que a seqüência é membro da família de proteínas (Pfam) citada. $\mathrm{O}$ valor $E$ é uma medida mais quantitativa da significância estatística, sendo que, quanto menor o valor $E$, maior a semelhança.

\subsection{Extração de DNA genômico}

O DNA genômico total foi extraído de folhas de batata e de eucalipto por meio do método CTAB (Doyle \& Doyle, 1987). Discos de $100 \mathrm{mg}$ de tecido foliar jovem foram coletados, congelados em nitrogênio líquido e armazenados a $-80^{\circ} \mathrm{C}$. As amostras depois de pulverizadas em cadinho de porcelana (previamente esterilizado a $200^{\circ} \mathrm{C}$, por 8 horas), com auxílio de nitrogênio líquido, foram transferidas para tubos eppendorf estéreis, contendo $700 \mu 1$ de tampão de extração com â-mercaptoetanol (Anexo R), previamente aquecido $\left(65^{\circ} \mathrm{C}\right)$, agitadas em vórtex e deixadas $15-20$ minutos a $55-60^{\circ} \mathrm{C}$, com homogeneização suave em intervalos de 5 minutos. As amostras foram deixadas à temperatura ambiente por 5 minutos, e em seguida, adicionourse $600 \mu \mathrm{l}$ de CIA. As amostras foram homogeneizadas invertendo-se os tubos 25 vezes e centrifugadas a $18.000 \times g$, a $4^{\circ} \mathrm{C}$, por 7 minutos.

O volume de $600 \mu \mathrm{l}$ da fase superior foi transferido para novo tubo (evitando-se perturbar a interface), ao qual foram adicionados $200 \mu$ l de tampão de extração, porém sem $\beta$-mercaptoetanol. Foram feitas duas extrações adicionais com $600 \mu \mathrm{l}$ de CIA, como descrito acima, para completa remoção da interface. 
A fase superior foi novamente transferida para novo tubo, à qual foram adicionados $600 \mu \mathrm{l}$ de isopropanol para a precipitação do DNA. Após homogeneização suave a amostra foi centrifugada a $18.000 \times \mathrm{g}$, a $4^{\circ} \mathrm{C}$, por 15 minutos.

O precipitado foi lavado com $600 \mu \mathrm{l}$ de etanol $70 \%$, e mantido a $-20^{\circ} \mathrm{C}$ por 20 minutos, antes da centrifugação por 15 minutos, a $4^{\circ} \mathrm{C}$, a 18.000 x $g$. Após secagem, o precipitado foi ressuspendido em $30 \mu \mathrm{l}$ de tampão TE (Anexo S) acrescido de $10 \mu \mathrm{g}$ de RNase e mantido a $37^{\circ} \mathrm{C}$, por 1 hora.

A qualidade e a quantidade de DNA foi verificada por me io de eletroforese. 5-10 $\mu \mathrm{l}$ da amostra foram aplicados em gel de agarose a $1 \%$ e as bandas visualizadas por meio de coloração com brometo de etídio $(0,01 \mathrm{ng} / \mu \mathrm{l})$ sobre luz ultravioleta (Sambrook et al, 1989).

\subsection{PCR com primers específicos para a ORF}

Com a finalidade de se verificar a autenticidade dos primers sintetizados específicos para a ORF do gene que codifica a UGPase, foi realizada a reação de PCR utilizando-se o DNA genômico total de batata e de eucalipto e os primers correspondentes à UGPase, conforme indicado no Anexo I, para um volume final de $50 \mu \mathrm{l}$ de reação. A amplificação do DNA de batata foi realizada com 2 minutos iniciais a $94^{\circ} \mathrm{C}$ e 38 ciclos de 15 segundos a $94^{\circ} \mathrm{C}, 30$ segundos a $55^{\circ} \mathrm{C}$ e 2,5 minutos a $72^{\circ} \mathrm{C}$. Já amplificação do DNA de eucalipto foi realizada com 2 minutos iniciais a $96^{\circ} \mathrm{C}, 3$ ciclos de 1 minuto a $96^{\circ} \mathrm{C}, 1$ minuto a $42^{\circ} \mathrm{C}$ e 2 minutos a $72^{\circ} \mathrm{C}$, mais 30 ciclos de 1 minuto a $96^{\circ} \mathrm{C}, 1$ minuto a $55^{\circ} \mathrm{C}$ e 2 minutos a $72^{\circ} \mathrm{C}$.

O produto de PCR (10 $\mu 1$ de cada reação) foi submetido à eletroforese em gel de $1 \%$ de agarose e as bandas visualizadas por meio de coloração com brometo de etídio $(0,01 \mathrm{ng} / \mu \mathrm{l})$ sobre luz ultravioleta (Sambrook et al, 1989). 


\subsection{Análise dos sítios de restrição}

Para a análise de Southern blot o DNA genômico total foi digerido com uma enzima de restrição que não reconhece sítios internos à ORF da UGPase e outro que reconhece. Com o auxílio do web site http://rebase.neb.com/rebase/rebtools.html- New England Biolabs NEBcutter - opção "List 0 cutters" definiu-se quais as enzimas que poderiam ser utilizadas.

\subsection{Southern blot}

Para a análise de Southern blot (Southern, 1975; Sambrook et al., 1989), $20 \mu \mathrm{g}$ de DNA genômico de batata e de eucalipto foram digeridas com as enzimas de restrição PstI e HindIII (Invitrogen), em excesso (50 unidades), de acordo com recomendações do fabricante, a $37^{\circ} \mathrm{C}$, por 16 horas. O DNA digerido foi precipitado pela adição de $1 / 10$ do volume de acetado de amônia e 2,5 vezes o volume de etanol absoluto. As amostras foram deixadas a $-20^{\circ} \mathrm{C}$ por $24-72$ horas. Após a centrifugação a 18.000 × $g$, por 40 minutos, a $4^{\circ} \mathrm{C}$, o precipitado foi lavado com $600 \mu \mathrm{l}$ de etanol $70 \%$, seguido de centrifugação e secagem, antes de ser ressuspendido em $40 \mu \mathrm{l}$ de TE (Anexo S). A este volume adicionourse $8 \mu \mathrm{l}$ de sacarose $40 \%$ para aumentar a densidade da amostra a ser submetida à eletroforese em gel de agarose 1\% em tampão TBE 0,5 X (Anexo G) e contendo brometo de etídio $(0,01 \mu \mathrm{g} / \mathrm{ml})$. Como marcador de peso molecular foi utilizado $1 \mathrm{~kb}$ DNA Ladder (Invitrogen). O gel foi submetido a uma corrente de $35 \mathrm{~V}$ por 15 horas e fotografado juntamente com uma régua visível sobre luz ultravioleta que permite correlacionar a altura da banda obtida ao correspondente peso molecular do marcador.

O DNA foi desnaturado por uma série de lavagens do gel, em solução ácida ( $\mathrm{HCl}$ $0,25 \mathrm{M})$ por 10 minutos para a depurinação, básica $(\mathrm{NaOH} 0,5 \mathrm{M} ; \mathrm{NaCl} 1,5 \mathrm{M})$ por 30 minutos para a desnaturação, e duas lavagens de 15 minutos cada para a neutralização ( $\mathrm{NaCl}$ 1,5 M; Tris- $\mathrm{HCl}$ 0,5 M pH=7,2; EDTA $1 \mathrm{mM}$ ), todas intercaladas com enxágües em água MilliQ estéril. 
A transferência por capilaridade do DNA do gel para a membrana de nylon Hybond-N+ (Amersham Pharmacia) foi carreada pela solução de transferência 20 X SSC (Anexo T) por 16 horas, de acordo com Sambrook et al. (1989). O DNA foi fixado à membrana por meio de aquecimento $\left(80^{\circ} \mathrm{C}\right)$ em forno, por duas horas.

O produto da reação de RT-PCR purificado com auxílio do kit Concert ${ }^{\mathrm{TM}}$ Nucleic Acid Purification System (Invitrogen), segundo protocolo do fabricante, foi utilizado como sonda para hibridização na análise de Southern blot. A sonda foi marcada de forma não radioativa, com auxílio do kit Gene Images $^{\mathrm{TM}}$ random prime labelling module (Amersham Pharmacia Biotech), segundo normas do fabricante.

Todos os passos da hibridização foram realizados no forno de hibridização. A membrana foi umedecida com $50 \mathrm{ml}$ de $5 \mathrm{X} \mathrm{SSC} \mathrm{(Anexo} \mathrm{T}$ ) à temperatura de $55^{\circ} \mathrm{C}$, durante 30 minutos. Essa solução foi substituída por $20 \mathrm{ml}$ de solução de préhibridização (Anexo U), onde a membrana foi deixada por pelo menos 1 hora, a $55^{\circ} \mathrm{C}$. A hibridização se deu por 16 horas após a adição da sonda marcada à solução de préhibridização. As lavagens de pós-hibridização da membrana foram realizadas com 100 $\mathrm{ml}$ de solução I (1 X SSC; SDS 0,1\% p/v) e 100 ml de solução II (0,5 X SSC; SDS 0,1\% $\mathrm{p} / \mathrm{v})$, a $55^{\circ} \mathrm{C}$, por 15 minutos cada.

A detecção dos pontos de hibridização foi realizada com auxílio do kit de detecção "Gene Images CDP-Star detection module", da Amersham Pharmacia Biotech. Após as lavagens pós-hibridização, a membrana foi mantida em solução bloqueadora (45 $\mathrm{ml}$ Buffer A (Anexo V); 1/10 v/v agente bloqueador de detecção fornecido pelo kit) por 1 hora, a temperatura ambiente. Em seguida, procedeu-se a incubação com o anticorpo antifluorescein-AP conjugate diluído (1:5000) em $25 \mathrm{ml}$ Buffer A + BSA 0,5\% p/v, a temperatura ambiente, por 1 hora. $\mathrm{O}$ excesso de anticorpo foi removido com três lavagens com $100 \mathrm{ml}$ de solução de lavagem (300 ml Buffer A + TWEEN-20 0,3\% v/v), de 10 minutos cada. Em capela de fluxo laminar, a membrana foi colocada sobre um plástico, e sobre ela distribuiu-se homogeneamente $300 \mu 1$ do reagente de detecção, 
fornecido pelo kit. A reação se deu durante 5 minutos. O excesso de líquido foi retirado com auxílio de uma régua, antes da selagem das bordas do saco plástico.

Numa câmara escura, um filme de autoradiografia foi exposto sobre a membrana hibridizada, mantida na ausência de luz no interior de um cassete de Raios X. A sensibilização do filme ocorre devido à reação luminosa resultante da oxidação do luminol (CDP-Star) em contato com a membrana hibridizada. O tempo de exposição do filme foi variável, iniciando-se com 30 segundos. Após a exposição, o filme foi revelado manualmente em câmara escura por meio da seguinte seqüência de lavagens: 4 minutos em solução reveladora GBX diluída (Kodak), 1 minuto em água, 15 minutos em solução fixadora GBX diluída (Kodak) seguida de lavagem em água corrente por 15 minutos. 


\section{RESULTADOS E DISCUSSÃO}

\subsection{Pesquisa em bancos de dados}

Pelas buscas nos bancos de dados genéticos do NCBI e KEGG foi possível obter uma relação de organismos cujo gene que codifica a enzima UGPase já foi seqüenciado. Este gene foi encontrado em uma ampla gama de organismos, desde bactérias até mamíferos. Em plantas, o gene já foi seqüenciado em Amorpha fruticosa, Arabidopsis thaliana, Hordeum vulgare, Musa acuminata, Oryza sativa, Pyrus pyrifolia e Solanum tuberosum, entre outras espécies.

\subsection{Similandade entre as UGPases de algumas espécies vegetais}

Foi feita uma análise comparativa através do programa Clustal W entre as sequiências completas de aminoácidos da UGPase de algumas espécies vegetais encontradas durante a busca do EC 2.7.7.9 no NCBI: Solanum tuberosum (batata) (gi|218001|dbj|BAA00570.1| |), Arabidopsis thaliana (gi|15237947|ref|NP_197233.1|), Oryza sativa (arroz) (gi|15823775|dbj|BAB69069.1|), Musa acuminata (banana) (gi|6625908|gb|AAF19422.1|AF203909_1), Hordeum vulgare (cevada) (gi|1212996| emb|CAA62689.1|), Amorpha fruticosa (gi|17026394|gb|AAL33919.1|) e Pyrus pyrifolia (pera asiática) (gi|19911799|dbj|BAB88218.1|) (Figura 4). 
CLUSTAL W (1.82) alinhamento múltiplo de sequências

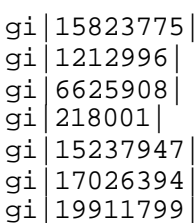

gi $|15823775|$

gi $1212996 \mid$

gi 6625908

gi $218001 \mid$

gi 15237947

gi 17026394

gi 19911799

gi $|15823775|$

gi 1212996

gi 6625908

gi 218001|

gi 15237947

gi 17026394

gi 19911799

gi 15823775

gi 1212996

gi 6625908

gi $218001 \mid$

gi 15237947

gi 17026394

gi $|19911799|$
MAVT ADVKI EGIRAATDKIDO ISENEKSGFT SLVSRYISGEAEO TEWSKIOTP T 54 ---MAAAAVAAD SKI DGLRDAVAKL GE ISENE KAGFISLV SR YLS GE AEQ IEWS KIQ TP T 57 -MAD AKI AKLQSAVAELNQISENEKSGFISLVSRYLS GEAEQ IEWSKIQ TP T 51 MAT AT TL SPADAEKLNNLKS AVAGLNOISENEKSGFINLVGRYLS GEAOH TDWS KIOTP T 60 -----MAAT AT EKL PQ LKS AVDGL TEMSENEKSGF INLV SRYLS GEAQH IEWS KIQ TP T 54 -----MAATA TD NKL SNLKS AVAGLNQISENE KKGF INLV SR YLS GEAQHVEWS KIQTP T 55 MATGVIDKLKS HVATLSOISENEKNGFTNLVARSVSGEAOHVDWSKTETP T 51

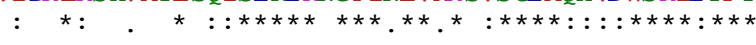

DEVVVPYDTLSAAPEDLNET KKLLD KLVVL KLNGGIGTTMGCTGP KSVIEVRNGFTF LDL 114 DEVVVPYDTLAPPPEDLDAMKALLDKLVVL KLNGGIGTTMGCTGP KSVIEVRNGFTF LDL 117 DEVVVPYDTLSP P PEDLEATKKLLDKLAVL KLNGGIGTTMGCTGP KSVIEVRNGFTF LDL 111 DEVVVPYDKLAPLSEDP AETKKLLD KLVVL KLNGG IGTTMGCTGP KSVIEVRNGLTF LD L 120 DEIVVPYDKMANVSEDASETKY LLDKLVVL KLNGGIGTTMGCTGP KSVIEVRDGLTF LDL 114 DEVVVPYESLAP TPD GS SEVKS LLDKLVVL KLNGGIGTTMGCTGP KSVIEVRDGLTF LDL 115 DEVVVPHAGLEPAPKDT AEI KALLDKLVVL KLNGG LGTTMGCTGP KSVIEVRDGLTF LD L 11

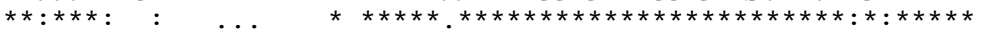

IVI OI ES LNKKYGCN VP LLLMN SFNTHDDT OK IVE KYSNSNI EIH TF NQSOYPR IVTEDF 174 IVIQI ES LNKKYGCS VPLLLMN SFNTHDDT OK IVEKYSNSNI EIH TF NQSQY PR IVTEDF 177 IVIQI ES LNKKYGCN VP LLLMN SFNTHDDT QK IVEKY ANSNI EIH TF NQSQY PRLVMEDF 171 IVKQI EA LNA KF GCSVP LLLMN SENTHDDT LK IVEKY ANSNI DIH TF NQSQY PRLVTEDF 180 IVIQI EN LNN KYNCKVP LVLMN SFNTHDDT QK IVE KY TKS NVDIH TF NQS KY PRVVADEF 174 IVIQI EN LNS KYGSN VP LLLMN SFNTHDDT QK I IEKY KNSNI QIH TF NQSQY PRLVVDDF 175 IVMQI EH LND KF GSS VP LLLMN SFNTHDDT OK IVE KY SKANVQIH TF NQSOY PRLVVDDF 171

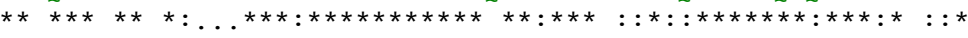

LPLPS KGKTGKD GWYPPGHGDVFP S INNSG KLDTLLAOGKEYVFVAN SDNIGA IVDI KI L 234 LPLPS KGQTG KD GWYPP GHGDVFP S INNSG KLDTLISOGKEYVFVAN SDNIGA IVDI KI L 237 QP LPS KG HA G KD GWYPP GHGDVFP S IMNSGKLDALISQGKEYVF IAN SDNIGA IVDI KI L 231 APLPC KGNSG KD GWYPPGHGDVFPS LMNSGKLDALTA KGKEYVFVAN SDNIGA IVDLKI L 240 VPWP S KGKTD KD GWYPP GHGDVFP S LMNSGKLDAF LSQGKEYVFIAN SDN LGA IVDL KI L 234 LPLPSKGHTG KD GWYPPGHGDVFP S ISNSG KLDALISQGKEYVFVAN SDNLGA IVDLKI L 235 TP LPS KGQTG KD GWYPPGHGDVFP S IKNSGKLDLLISOGREYVFI SN.SDNIGA IVDLKI L 231

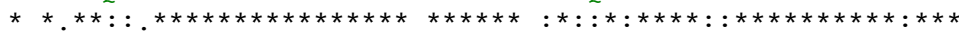

Figura 4 Alinhamento das seqüências deduzidas de aminoácidos da enzima UGPase de Oryza sativa (gi|15823775|), Hordeum vulgare (gi|1212996|), Musa acuminata (gi|6625908|), Solanum tuberosum (gi|218001|), Arabidopsis thaliana (gi|15237947|), Amorpha fruticosa (gi|17026394|) e Pyrus pyrifolia (gi|19911799|), através do programa ClustalW. Os asteriscos indicam resíduos idênticos, dois pontos indicam substituições conservadas, um ponto indica variação em uma ou mais sequiências e os traços indicam os intervalos introduzidos para otimizar o alinhamento 


$$
\begin{array}{l|l|}
\text { gi } & 15823775 \mid \\
\text { gi } & 1212996 \mid \\
\text { gi } & 6625908 \mid \\
\text { gi } & 218001 \mid \\
\text { gi } & 15237947 \\
\text { gi } & 17026394 \\
\text { gi } & 19911799
\end{array}
$$

gi $|15823775|$

gi 1212996

gi 6625908|

gi 218001|

gi 15237947

gi 17026394

gi $19911799 \mid$

gi $|15823775|$

gi 1212996

gi 6625908

gi 218001|

gi 15237947

gi 17026394

gi $|19911799|$

gi $|15823775|$

gi 1212996

gi 6625908

gi 218001|

gi 15237947

gi 17026394

gi 19911799
NHL IHNQNEY OMEVT PK TLADVKG GL ISY EGRVQLLEIA QVPDE HVNEF KS IEKFK IFN 294 NHL IHNQNEY QMEVT PK TLADV KGG TL ISY EG RVQ LLEIA QVPDE HVDEF KS IEKFK IF N 297 NHL INNQNEY CMEVT PK TLADVVKGG IL ISY EGRVQLLEIA QVPDA HVNEF KS IE KFK IFN 291 NHL I L NKNEY CMEVT PK TLADVKG G TL ISY EGKVQ LLE IA QVPDE HVNEF KS IE KFK IF N 300 KHL IONKNEY CMEVT PK TLADV KGGTL ISY EG KVO LLEIA OVPDE HVNEF KS IE KFK IFN 294 NHLVKNKNEY CMEVT PK TLADVKGGTL ISY EGRVQ LLEIA QVPDE HV SEF KS IEKFK IFN 295 HHL IKNKNEY IMEVT PK TLADVKG G TL ISY EGKVQ LLEIA QVPEE HVDEF KS IE KFK IFN 291

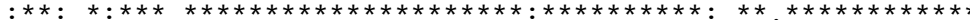

TNNLWVNLKA IKRLVEAEAL KMEI I PNPKEVD GVKVLQLE TAAGAAIRFF EKAI GINVP R 354 TNNLWVNLKA IKRLVDA EALKMEI I PNPKEVD GVKVLQLE TAAGAAIRFF EKAI GINVP R 357 TNNLWVNLKA IKRLVEADAL KMEI I PNPKEVD GVKVLQLE TAAGAAIRFF DHAI GINVP R 351 TNNLWVNLSA IKRLVEADAL KMEI I PNPKEVD GVKVLQLE TAAGAAIKFF DRAI GANVP R 360 TNNLWVNLKA IKKLVEADALKMEI I PNPKEVD GVKVLQLE TAAGAAIRFF DNAI GVNVP R 354 TNNLWVNLKA TKRLVEADALKT EI I PNPKEVD GVKVLOLE TAAGAA IRFF DKAI GTNVPR 355 TNNLWVNLNA IKRLVDADAL KMEI I PNPKEVD GVKVLQLE TAAGAAIKFF DNAI GINVP R 351

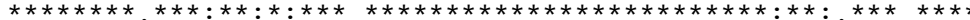

SRFLPVKATSDLLLV QSDLY TLVDG-FVIRNP ARTNP SNP SIELGPEFKKVANFLARFKS 413 SRF LPVKATS DLLLV OSDLY TLVDG-YVIRNP ARVKP SNP SI ELGPEFKKVANFLARFKS 416 SRFLPVKATS DLLLV QSDLYMLVDG-FVIRNKARTNP SNP SI ELGPEFKKVANF LSRFKS 410 SRF LPVKATS DLLLV QSDLY TL TDE GYVIRNP ARSNP SNP SI ELG PE FKKVANF LGRFKS 420 SRFLPVKATS DLLLV QSDLY TLVDG-FVTRNKARTNP TNPAIELGPEFKKVASF LSRFKS 413 SRF LPVKATS DLLLV OSDLY TLEDG-FVIRNKARANP ENP TVELGPEFKKVSNF LSRFKS 414 ARF LPVKATS DLLLV KS DLYNVRDG-FVIRNK LRRDP QNP I IQLG PEFKKVD DF LSRFKS 410

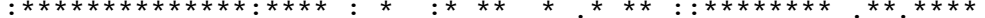

IPS IVEULTLKV SGDVWFGS GV TLK GKVTI TAKSG-KLEI PD GAVIENKD INGP EDL 469 IPS IVELDSLKV SGDVSFGS GVVLKGNVTIAAKAGVKLEI PD GAVIENKD INGP EDI 473 IPS IVELDSL KV SGDVWFGE GVVLK GNVS IAAKSGVKLEI SD GAVIENKV INGP EDI 467 IPS I I DLDSLKV TGDVWFGSGV TLK GKVTVAAKSGVK LEIPD GAVIANKD INGPP EDI 477 IPS IVELDSL KV SGDVWFGS GVVLKGKVTVKANAGTKLEI PDNAVIENKD TNGP EDL 470 IPS IVELDSLKVAGDVWFGP GI ILK GKVS IVAKPGVKLEI PD GAVIA NKE INGP EDL 471 IPS LLECDGLRVD GD IWFG S GI KLK GNVHC SV SSE EMLNI PDNIT LRE--------- 458

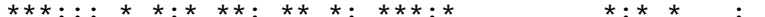

Figura 4 Alinhamento das sequiências deduzidas de aminoácidos da enzima UGPase de Oryza sativa (gi|15823775|), Hordeum vulgare (gi|1212996|), Musa acuminata (gi|6625908|), Solanum tuberosum (gi|218001|), Arabidopsis thaliana (gi|15237947|), Amorpha fruticosa (gi|17026394|) e Pyrus pyrifolia (gi|19911799|), através do programa ClustalW. Os asteriscos indicam resíduos idênticos, dois pontos indicam substituições conservadas, um ponto indica variação em uma ou mais sequiências e os traços indicam os intervalos introduzidos para otimizar o alinhamento 
Pela análise verificourse a ocorrência de alinhamento biologicamente significativo entre as UGPases dessas espécies o que indica que a enzima é altamente conservada evolutivamente. Porém, as extremidades $\mathrm{N}$ e $\mathrm{C}$ terminais não são conservadas, o que dificulta a confecção de um par de primers que pudesse ser utilizado na amplificação do gene independentemente da espécie vegetal.

A sequiência deduzida de aminoácidos de enzimas bacterianas são 30-40\% mais curtas do que UGPase de eucariotos, mas suas propriedades catalíticas e regulatórias são semelhantes (Hossain et al., 1994). A alta identidade entre UGPase de cevada e as correspondentes proteínas de outros tecidos vegetais e animais, mas não de bactéria, sustenta uma visão mais recente (Hossain et al., 1994) de que genes de UGPase de eucariotos e procariotos ramificaram-se em um estágio evolutivo bem recente. Por outro lado, os genes podem ter evoluído independentemente por meio de convergência evolutiva a partir de diferentes proteínas progenitoras (Eimert et al, 1996).

\subsection{Similaridade entre UGPases de alguns cultivares de batata}

A falta de alinhamento das extremidades das seqüências de aminoácidos de diferentes espécies vegetais levou à escolha de uma única espécie, Solanum tuberosum (batata), da qual foram selecionados os gi(s) number of general identification) que apresentavam a sequiência completa (complete $c d s$ ) para a UGPase (Tabela 1), relacionados a diferentes cultivares da espécie. As sequiências deduzidas dos 477 aminoácidos da UGPase de batata de cada gi foram utilizadas na busca de similaridade através do programa Clustal W (Figura 5).

Entre os diferentes gi(s) de batata originados de diferentes cultivares da espécie Solanum tuberosum encontrou-se também um alinhamento biologicamente significativo, com diferença em apenas 14 dos 477 aminoácidos, e com melhor alinhamento nas extremidades $\mathrm{N}$ e $\mathrm{C}$ terminais. 
Tabela 1. Relação de gi(s) do GenBank para a UGPase de diferentes cultivares de batata

\begin{tabular}{llll}
\hline $\begin{array}{c}\text { Número de Acesso } \\
\text { ao GenBank }\end{array}$ & \multicolumn{1}{c}{ GI } & \multicolumn{1}{c}{ Protein id } & \multicolumn{1}{c}{ Cultivar $^{\text {B }}$} \\
\hline D00667.1 & 218001 & BAA00570.1 & Danshaku-Imo $^{(1)}$ \\
Z18924.1 & 21599 & CAA79357.1 & Desiree $^{(2)}$ \\
U20345.1 & 1388021 & AAB71613.1 & Lemhi $^{(3)}$ \\
AY082617.1 & 28863903 & AAL99192.1 & Snowden $^{(4)}$ \\
AY082618.1 & 28863905 & AAL99193.1 & ND860-2 $^{(4)}$ \\
AY082619.1 & 28863907 & AAL99194.1 & Russet Burbank-1 $^{(4)}$ \\
AY082620.1 & 28863909 & AAL99195.1 & Norchip $^{(4)}$ \\
AY082621.1 & 28863911 & AAL99196.1 & Redsen $^{(4)}$ \\
AY082622.1 & 28863913 & AAL99197.1 & BelRus $^{(4)}$ \\
AY082623.1 & 28863915 & AAL99198.1 & Russet Burbank-2 $^{(4)}$ \\
\hline
\end{tabular}

Referências: (1) Katsube et al., 1990; (2) Spychalla et al., 1994; (3) Borovkov et al., 1997; (4) Sowokinos et al. ${ }^{1}, 2002$.

1 SOWOKINOS, J.R.; VIGDOROVICH, V.; ABRAHAMSEN, M.S. Molecular cloning and sequence anomalies of UDP-glucose pyrophosphorylase cDNAs from cold-sweetening-sensitive and resistant potatoes. Trabalho não publicado. 


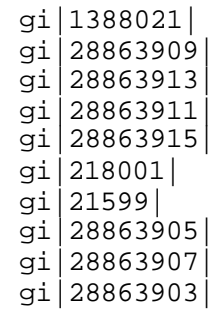

gi | $1388021 \mid$

gi 28863909

gi 28863913

gi 28863911

gi 28863915

gi 218001

gi 21599 |

gi 28863905

gi 28863907

gi 28863903

gi $1388021 \mid$

gi 28863909

gi 28863913

gi 28863911

gi 28863915

gi 218001|

gi 21599

gi 28863905

gi 28863907

gi|28863903

gi | 1388021 |

gi 28863909

gi 28863913

gi 28863911

gi 28863915

gi 218001|

gi 21599

gi 28863905

gi 28863907

gi 28863903
MVT AT TL SPADAEKLNNLKS AVAGLNOISENE KSGF INLV GRYLS GEAOH IDWS KIO TP T 60 MAT AT TL SPADAEKLNNLKS AVAGLNQISENE KSGF INLV GRYLS GEAQH ID WS KIQ TP T 60 MAT AT TL SPADAEKLNNLKS AVAGLNQISENEKSGF INLVGRYLS GEAQH IDWS KIQTP T 60 MAT AT TL SPADAEKLNNLKS AVAGLNOISENEKSGFINLVGRYLS GEAOH IDWS KIO TP T 60 MATAT TL SPADAEKLNNLKS AVAGLNQISENEKSGF INLVGRYLS GEAQH IDWS KIQTP T 60 MATAT TL SPADAEKLNNLKSAVAGLNQISENEKSGFINLVGRYLSGEAQH IDWS KIQTP T 60 MAT AA TL SPADAEKLNNLKS AVAGLNOISDNEKSGFINLVGRYLS GEAOH IDWS KIOTP T 60 MAT AA TL SPADAEKLNNLKS AVAGLNQISDNE KSGF INLV GRYLS GEAQH IDWS KIQTP T 60 MAT AA TL SPADAEKLNNLKS AVAGLNQISDNEKSGF INLVGRYLS GEAQH IDWS KIQTP T 60 MAT AA TL SPADAEKLNNLKS AVAGLNQISDNE KSGF INLV GRYLS GEAOH IDWS KIO TP T 60

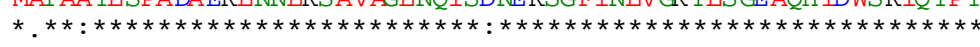

DEVVVPYDKLAPLSEDP AET KKLLDKLVVL KLNGGIGTTMGCTGP KSVIEVRNGLTF LD L 120 DEVVVPYDKLAPLSEDP AET KKLLDKLVVL KLNGGIGTTMGCTGP KSVIEVRNGLTF LDL 120 DEVVVPYDKLAPLSEDP AET KKLLD KLVVL KLNGGIGTTMGCTGP KSVIEVRNGLTF LDL 120 DEVVVPYDKLAPLSEDP AET KKLLD KLVVL KLNGGIGTTMGCTGP KSVIEVRNGLTF LD L 120 DEVVVPYDKLAPLSEDP AET KKLLDKLVVL KLNGGIGTTMGCTGP KSVIEVRNGLTF LDL 120 DEVVVPYDKLAPLSEDP AET KKLLD KLVVL KLNGGIGTTMGCTGP KS VIEVRNGLTF LDL 120 DEVVVPYDKLAPLSEDP AET KNLLD KLVVL KLNGG IGTTMGCTGP KSVIEVRNGLTF LD L 120 DEVVVPYDKLAPLSEDP AET KNLLDKLVVL KLNGGIGTTMGCTGP KSVIEVRNGLTF LDL 120 DEVVVPYDKLAPLSEDP AET KN LLDKLVVL KLNGGIGTTMGCTGP KSVIEVRNGLTF LDL 120 DEVVVPYDKLAPLSEDP AET KNLLD KLVVL KLNGGIGTTMGCTGP KSVIEVRNGLTF LDL 120

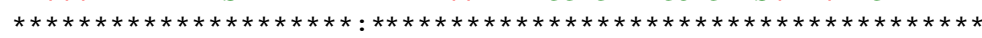

IVKOI EA LNA KF GCS VP LLLMN SFNTHDDT IK IVE KY ANSNI DIH TF NQSQY PRLVTEDF 180 IVKQI EA LDA KF GCS VP LLLMN SFN TRDDT IR IVE KY AN SNI DIH TF NQSQY PRLVTEDF 180 IVKQI EA LNA KF GCS VP LLLMN SENTHDDT IK IVE KY ANSNI D IH TF NQSQY PRLVTEDF 180 IVKOI EA LNA KF GCSVPLLLMN SFNTHDDT IK IVEKY ANSNI DIH TF NOSOY PRLVTEDF 180 IVKQI EA LNA KF GCS VP LLLMN SFNTHDDT IK IVE KY AN SNI DIH TF NQSQY PRLVTEDF 180 IVKQI EA LNA KF GCS VP LLLMN SENTHDDT IK IVE KY ANS NI D IH TF NQSQY PRLVTEDF 180 IVKOI EA LNA KF GCS VP LLLMN SFNTHDDT IK IVE KY AN SNI D IH TF NQSOY PRLVTEDF 180 IVKQI EA LNA KF GCS VP LLLMN SFNTHDDT IK IVE KY AN SNI DIH TF NQSQY PRLVTEDF 180 IVKQI EA LNA KF GCS VP LLLMN SENTHDDT IK IVEKY ANSNI D IH TF NQSQY PRLVTEDF 180 IVKQI EAFNAKF GCS VP LLLMN SFNTHDDT IK IVEKY ANSNI D IH TF NQSQY PRLVTEDF 180

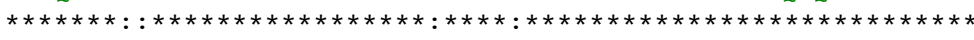

APLPCKGNSG KD GWYPP GHGDVFP S LMNSGKLDALIA KGKEYVFVAN SDN LGA IVDL KI L 240 APLPCKGNSG KD GWYPPGHGDVFP S LMNSGKLDALLA KGKEYVFVANSDNIGA IVDLKI L 240 APLPC KGNSG KD GWYPP GHGDVFP S LMNSGKLDALLA KGKEYVFVAN SDN LGA IVDL KI L 240 APLPCKGNSG KD GWYPPGHGDVFP S LMNSGKLDALIA KGKEYVFVAN SDN LGA IVDLKI L 240 APLPCKGNSG KD GWYPP GHGDVFP S LMNSGKLDALLA KGKEYVFVAN SDNIGA IVDLKI L 240 APLPCKGNSG KD GWYPP GHGDVFP S LMNSGKLDALLA KGKEYVFVAN SDN LGA IVDLKI L 240 APLPCKGNSG KD GWYPP GHGDVFP S LMNSGKLDALIA KGKEYVFVAN SDN LGA IVDLKI L 240 APLPCKGNSG KD GWYPPGHGDVFP S LMNSGKLDALLA KGKEYVFVAN SDNLGA IVDLKI L 240 APLPCKGNSG KD GWYPPGHGDVFP S LMNSGKLDALIA KGKEYVFVAN SDNIGA IVDL KI L 240 APLPC KGNSG KD GWYPP GHGDVFP S LMNSGKLDALIA KGKEYVFVAN SDN LGA IVDL KI L 240

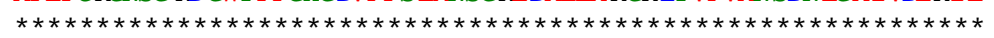

Figura 5- Alinhamento obtido pelo programa ClustalW, das sequiências deduzidas de aminoácidos da enzima UGPase de diferentes cultivares de Solanum tuberosum (batata):. Lemhi (gi|1388021|), Norchip (gi|28863909), BelRus (gi|28863913|), Redsen (gi|28863911|), Russet Burbank-2 (gi|28863915|), Danshaku-Imu (gi|218001|), Desiree (gi|21599|), ND860-2 (gi|28863905|)， Russet Burbank-1 (gi|28863907|) e Snowden (gi|28863903|). Os asteriscos indicam resíduos idênticos, dois pontos indicam substituições conservadas e um ponto indica variação em uma ou mais seqüências 


$$
\begin{array}{l|l|}
\text { gi } & 1388021 \mid \\
\text { gi } & 28863909 \\
\text { gi } & 28863913 \\
\text { gi } & 28863911 \\
\text { gi } & 28863915 \\
\text { gi } & 218001 \mid \\
\text { gi } & 21599 \mid \\
\text { gi } & 28863905 \\
\text { gi } & 28863907 \\
\text { gi } & 28863903
\end{array}
$$

gi|1388021|

gi 28863909

gi 28863913

gi 28863911

gi 28863915

gi $218001 \mid$

gi 21599|

gi 28863905

gi 28863907

gi $28863903 \mid$

gi $1388021 \mid$

gi 28863909

gi 28863913

gi 28863911

gi 28863915

gi 218001 |

gi 21599|

gi 28863905

gi 28863907

gi 28863903

gi|1388021|

gi 28863909

gi 28863913

gi 28863911

gi 28863915

gi 218001|

gi 21599|

gi 28863905

gi 28863907

gi 28863903
NHL ILNKNEY CMEVT PK TLADVKG GTL ISY EGKVQLLEIA QVPDE HVNEF KS IE KFK IF N 300 NHLI L NKNEY CMEVT PK TLADVKG GTL ISY EGRVQLLEIA QVPDE HVNEF KS IE KFK IFN 300 NHL IL NKNEY CMEVT PK TLADVKGGTL ISY EGKVQLLEIA OVPDE HVNEF KS IEKFK IFN 300 NHL I LNKNEY CMEVT PK TLADVKG GTL ISY EGKVQLLEIA QVPDE HVNEF KS IE KFK IFN 300 NHLI L NKNEY CMEVT PK TLADVKGGTL ISY EGKVQLLEIA QVPDE HVNEF KS IE KFK IFN 300 NHLIL NKNEY OMEVT PK TLADVKGGTL ISY EGKVQ LLEIA OVPDE HVNEF KS IE KFK IFN 300 NHL I LNKNEY CMEVT PK TLADVKG G IL ISY EGKVQLLEIA QVPDE HVNEF KS IE KFK IFN 300 NHLI L NKNEY CMEVT PK TLADVKG GTL ISY EGKVQLLEIA QVPDE HVNEF KS IE KFK IFN 300 NHL I L NKNEY CMEVT PK TLADVKGG IL ISY EGKVQLLEIA QVPDE HVNEF KS IE KFK IFN 300 NHL ILNKNEY CMEVT PK TLADVKGG IL ISY EGKVQ LLEIA QVPDE HVNEF KS IE KFK IF N 300

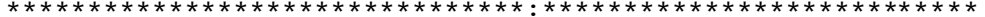

TNNLWVNLSA IKRLVEADAL KMEI I PNPKEVD GVKVLQLE TAAGAAIKFF DRAI GANVP R 360 TNNLWVNLSA TKRLVEADALKMEI I PNPKEVD GVVVLOLE TAAGAAIKFF DRAI GANVPR 360 TNNLWTNLSA TKRLVFAVAL KMEI I PNPKEVD GVVVLOLE TAAGAAIKFF DRAI GANVPR 360 TNNLWVNLSA IKRLVEADAL KMEI I PNPKEVD GVKVLQLE TAAGAAIKFF DRAI GANVP R 360 TNNLWVNLSA IKRLVEADAL KMEI I PNPKEVD GVKVLQLE TAAGAA IKFF DRAI GANVPR 360 TNNLWVNLSA TKRLVFADAL KMEI I PNPKEVD GVKVLOLE TAAGAA IKFF DRAI GANVPR 360 TNNLWVNLSA IKRLVEADAL KMEI I PNPKEVD GVKVLQLE TAAGAAIKFE DRAI GANVP R 360 TNNLWVNLSA TKRLVFADAL KMEI I PNPKEVD GVKVLOLE TAAGAAIKFF DRAI GANVP R 360 TNNLWVNLSA IKRLVEADAL KMEI I PNPKEVD GVKVLQLE TAAGAAIKFF DRAI GANVP R 360 TNNLWVNLSA VKRLVEADAL KMEI I PNPKEVD GVKVLQLE TAAGAAIKFF DRAI GANVP R 360

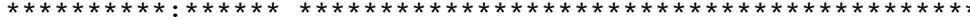

SRFLPVKATS DLLLV QSDLY TL TDE GYVIRNP ARSNP SNP SIELGPEFKKVANF LGRFKS 420 SRF LPVNATS DLLLV OSDLY TL TDE GYVIRNP ARSNP SNP SI ELGPEFKKVANF LGRFKS 420 SRF LPVKATS DLLLV OSDLY TL TDE GYVIRNP ARSNP SNP SI ELGPEFKKVANF LGRFKS 420 SRF LPVKATS DLLLV QSDLY TL TDE GYVIRNP ARSNP SNP SI ELG PE FKKVANF LGRFKS 420 SRF LPVKATS DL LLVOSDLY TL TDE GYVIRNP ARSNP SNP SI ELG PE FKKVANF LGRFKS 420 SRF LPVKATS DLLLV OSDLY TL TDE GYVIRNP ARSNP SNP SI ELGPEFKKVANF LGRFKS 420 SRF LPVKATS DLLLV QSDLY TL TDE GYVIRNP ARS NP SNP SI ELGPEFKKVANF LGRFKS 420 SRFLPVKATSDTLIV OSDLYTT TDE GYVIRNPARSNP SNP SI ELGPE FKKVANF LGRFKS 420 SRF LPVKATS DLLLV QSDLY TL TDE GYVIRNP ARSNP SNP SI ELGPEFKKVANF LGRFKS 420 SRFLPVKATS DLLLV QSDLY TL TDEGYVIRNP ARSNP SNP SI ELGPEFKKVANF LGRFKS 420

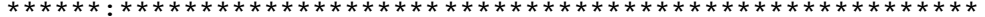

IPS I I DLDSLKV TGDVWFGSGV TLKGKVTVAAKSGVKLEIPD GAVIANKD INGPP EDI 477 IPS I I DLDSLKV TGDVWFGSGVTLKGKVTVAAKSGVK LEI PD GAVIA NKD INGP EDI 477 IPS I I DLDSL KV TGDVWFG S GV TLK GKVTVAAKSGVK LEI PD GAVIA NKD INGP EDI 477 IPS I I DLDSLKV TGDVWFGS GV TLKGKVTVAAKSGVKLEI PD GAVIA NKD INGP EDI 477 IPS I I DLDSLKVTGDVWFGSGVTLK GKVTVAAKSGVKLEI PD GAVIA NKD TNGP EDT 477 IPS IIDLDSL KVTGDVWFGS GVTLK GKVTVAAKSGVK LEI PD GAVIA NKD TNGP EDI 477 IPS I I DLDSLKV TGDVWFGSGVTLE GKVTIAAKSGVKLEI PD GAVIA NKD INGP EDI 477 IPS I IDLDSLKV TGDVWFGS GV TLE GKVTIAAKSGVK LEI PD GAVIA NKD INGP EDI 477 IPS I IDLDSLKVTGDVWFGS GV TLEGKVTIAAKSGVKLEI PD GAVIA NKD INGP EDI 477 IPS I I DLDSLKVTGDVWFGS GVTLE GKVTIAAKSGVKLEI PD GAVIA NKD INGGP EDI 477

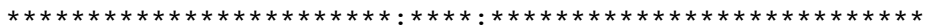

Figura 5- Alinhamento, obtido pelo programa ClustalW, das sequiências deduzidas de aminoácidos da enzima UGPase de diferentes cultivares de Solanum tuberosum (batata):. Lemhi (gi|1388021|), Norchip (gi|28863909), BelRus (gi|28863913|), Redsen (gi|28863911|), Russet Burbank-2 (gi|28863915|), Danshaku-Imu (gi|218001|), Desiree (gi|21599|), ND860-2 (gi|28863905|) , Rus set Burbank-1 (gi|28863907|) e Snowden (gi|28863903|). Os asteriscos indicam resíduos idênticos, dois pontos indicam substituições conservadas e um ponto indica variação em uma ou mais seqüências 


\subsection{Definição dos primers para a ORF}

A similaridade entre as seqüências de aminoácidos permitiu a confecção de um par de primers que pôde ser utilizado na amplificação do gene UGPase da batata, independentemente do tipo de cultivar. Esses primers foram definidos por meio do alinhamento entre os 21 nucleotídeos das extremidades 5' e 3' de dez gi(s) de batata, com auxílio do programa Clustal W (Figura 6).

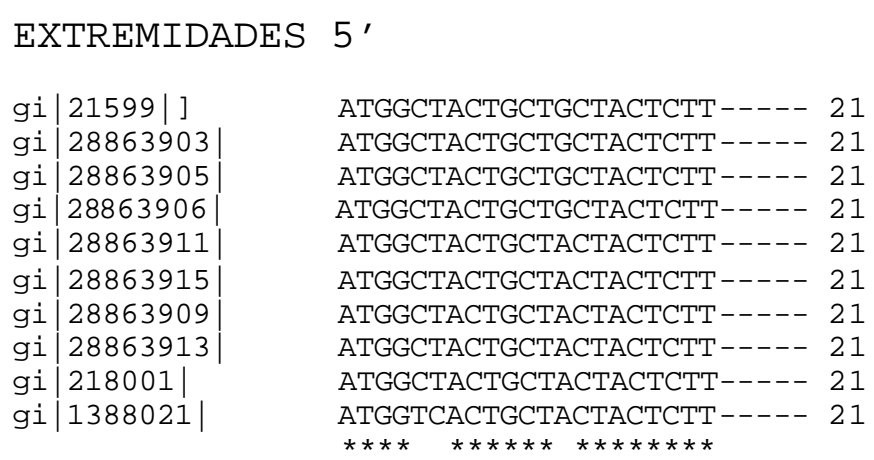

EXTREMIDADES $3^{\prime}$

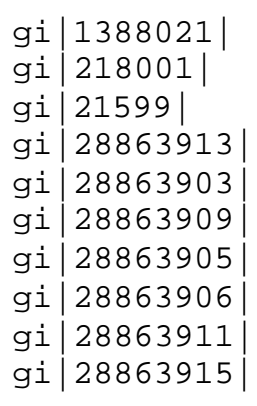

AATGGACCTGAGGATATATAG 21 AATGGACCTGAGGATATATAG 21 AATGGACCTGAGGATATATAG 21 AATGGACCTGAGGATATATAG 21 AATGGACCTGAGGATATATAG 21 AATGGACCTGAGGATATATAG 21 AATGGACCTGAGGATATATAG 21 AATGGACCTGAGGATATATAG 21 AATGGACCTGAGGATATATAG 21 AATGGACCTGAGGATATATAG 21

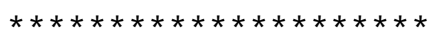

Figura 6 Alinhamento das seqüências de nucleotídeos das extremidades 5' e 3' dos diferentes gi(s) de batata por meio do programa ClustalW, para a definição do par de primers específico para a UGPase. Os asteriscos indicam resíduos idênticos em todas as seqüências 
No alinhamento das extremidades 5', as $5^{\mathrm{a}}$ e $6^{\mathrm{a}}$ bases diferiram apenas para o gi|1388021|. Como estas duas bases encontram-se invertidas em relação às demais sequiências pode ter havido um artifício de sequenciamento. Desta forma, esta diferença não foi considerada. A $13^{\mathrm{a}}$ base também variou, porém, em um número maior de sequiências. Assim, nesta posição, o Primer Sense foi confeccionado com 50\% de adenina e 50\% de guanina, indicadas pela letra R (purina). Já no caso do Primer Antisense, o alinhamento das extremidades 3 ' foi perfeito. A sequiência de direcionamento CACC do sistema Directional TOPO ${ }^{\circledR}$ foi adicionada à extremidade 5' do PrimerSense. Portanto, os primers sintetizados foram:

\section{Primer Sense $\rightarrow$ 5' CACCATGGCTACTGCTRCTACTCTT 3' Primer Antisense $\rightarrow$ 5' CTATATATCCTCAGGTCCATT 3'}

Pelo programa Primer3 verificouse a viabilidade destes primers. A única desvantagem encontrada foi a temperatura de ane lamento $(\mathrm{Tm})$ muito baixa $\left(53\right.$ e $\left.54^{\circ} \mathrm{C}\right)$, o que não prejudica seu funcionamento.

A especificidade dos primers foi confirmada com auxílio do programa Nucleotide Blast (Search for short nearly exact matches) no banco de dados do NCBI, uma vez que se encontrou $100 \%$ de identidade ao gene de interesse da batata.

\subsection{Reação de RT-PCR}

O mRNA, purificado a partir de RNA total de batata, foi utilizado na reação de RT-PCR com primers específicos para a ORF da UGPase. O produto de amplificação de $1,4 \mathrm{~kb}$, correspondente à ORF da UGPase, foi visualizado por meio de eletroforese (Figura 7). 


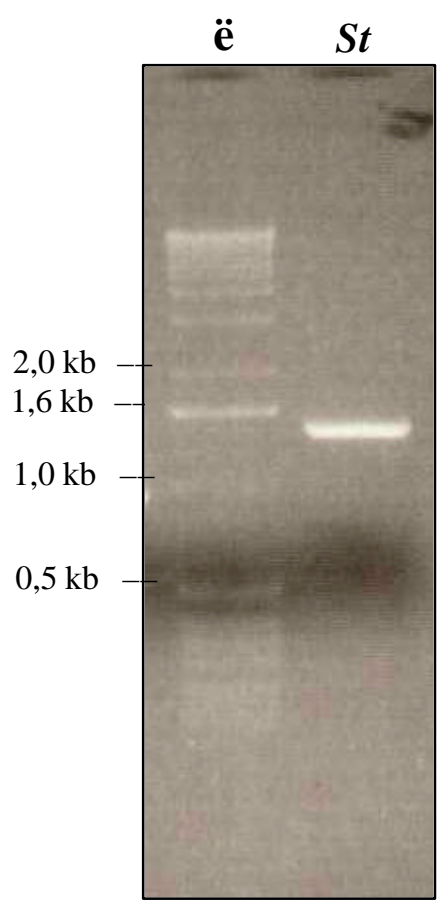

Figura 7 Perfil eletroforético do produto de RT-PCR obtido com primers específicos para amplificar o gene da UGPase $(1,4 \mathrm{~kb})$ de Solanum tuberosum $(\boldsymbol{S t})$. A primeira

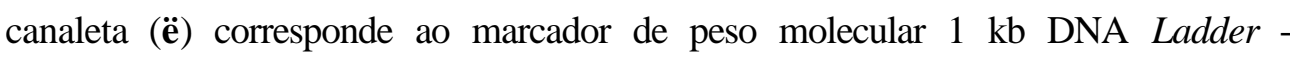
Invitrogen

\subsection{Análise de colônias transformantes por PCR}

Os fragmentos obtidos na reação de RT-PCR foram clonados ao vetor pENTR-D $\mathrm{TOPO}^{\circledR}$. O vetor recombinante foi utilizado na transformação de células quimicamente competentes da linhagem de E. coli TOP10, da Invitrogen. As células transformadas foram selecionadas em meio LB sólido acrescido de canamicina, após um período de 16 horas, a $37^{\circ} \mathrm{C}$, e submetidas à confirmação da presença do transgene, via $\mathrm{PCR}$, na presença de primers específicos para a ORF.

O produto de amplificado na reação PCR correspondente a aproximadamente 1,4 $\mathrm{kb}$ foi obtido somente para o caso do clone $\mathrm{n}^{\mathrm{o}} 2$ (Figura 8). 


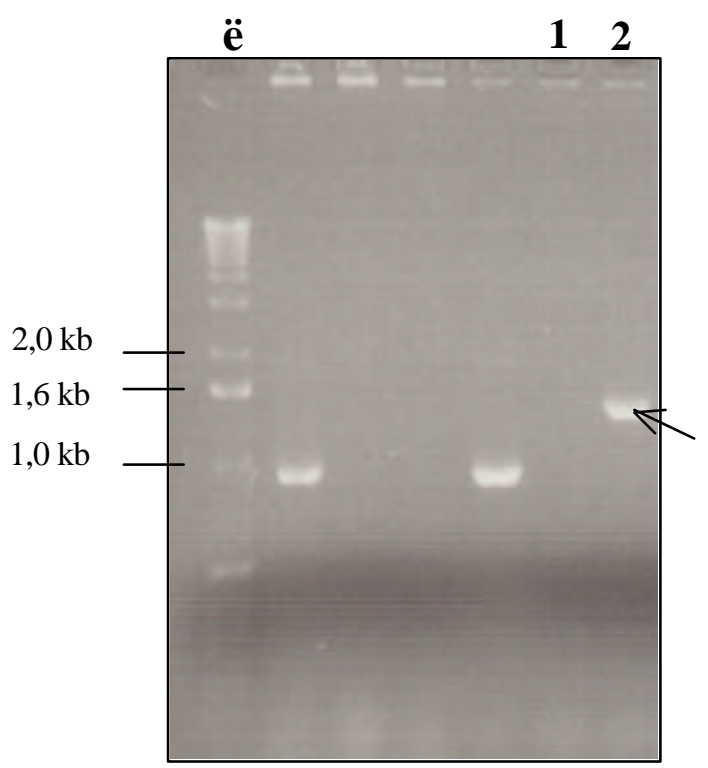

Figura 8 Perfil eletroforético obtido na análise dos clones transformantes. A primeira canaleta corresponde ao marcador de peso molecular $1 \mathrm{~kb}$ DNA Ladder - Invitrogen (̇̈). A sexta e sétima canaletas correspondem ao produto de PCR dos clones $\mathbf{1}$ e $\mathbf{2}$, respectivamente

\subsection{Seqüenciamento de DNA plasmidial}

O DNA plasmidial extraído do clone (2) que amplificou corretamente na análise de clones transformantes foi seqüenciado nos dois sentidos utilizando-se o par de primers universais M13. As seqüências parciais obtidas e alinhadas por meio do programa Blast 2 Sequences (página eletrônica do NCBI) resultaram em uma seqüência consenso. Nesta seqüência foi possível reconhecer as bases correspondentes ao DNA do inserto e, na sua extremidade 5', as bases correspondentes ao DNA plasmidial. O inserto clonado apresentou $1402 \mathrm{pb}$, sendo que 12 delas não foram identificadas, e a proteína deduzida, 467 aminoácidos. Os tamanhos são próximos ao tamanho da ORF (1434 pb) e a da proteína deduzida (477 aminoácidos) obtidos para a UGPase de tubérculos de batata por Katsube et al. (1990), Spychalla et al (1994), Borovkov et al. (1997) e Sowokinos et al. (2002). No sequenciamento não consta a série de bases do DNA plasmidial adjacente à extremidade 3' do inserto e portanto, o sequenciamento não abrangeu toda a seqüência 
compreendida entre os sítios de anelamento dos primers M13. Desta forma, o tamanho menor (-32 pb) encontrado não significa necessariamente que o inserto não esteja completo. A seqüência consenso do inserto e a correspondente seqüência deduzida de aminoácidos, de acordo com o código IUPAC (Anexo A), encontram-se na Figura 9.

Estudos anteriores sobre UGPase de tubérculos de batata permitiram a identificação de três resíduos de lisina no interior da estrutura protéica que são críticos para a catálise $\left(\mathrm{K}^{367}\right)$ e para a ligação do substrato $\left(\mathrm{K}^{263}\right.$ e $\left.\mathrm{K}^{329}\right)$ pirofosfato e/ou áDglicose 1-fosfato à enzima (Katsube et al., 1991; Kazuta et al, 1991). As posições dos três resíduos lisina no sítio ativo putativo da enzima são conservadas na enzima do fígado bovino $\left(\mathrm{K}^{291}, \mathrm{~K}^{357}, \mathrm{~K}^{396}\right)$ (Konishi et al, 1993), duas são encontradas na seqüência protéica de Saccharomyces cerevisae $\left(\mathrm{K}^{280}, \mathrm{~K}^{388}\right.$ ) (Daran et al., 1995), e pelo menos uma $\left(\mathrm{K}^{287}\right)$ é conservada na seqüência de $E$. coli (Hossain et al, 1994). O cDNA aqui clonado tem resíduos lisina em posições idêntic as $\left(\mathrm{K}^{263}, \mathrm{~K}^{329}, \mathrm{~K}^{367}\right)$ às citadas para a batata.

A seqüência deduzida de aminoácidos da UGPase de batata aqui obtida contém dois sítios putativos de $\mathrm{N}$-glicosilação (Figura 9) que podem estar relacionados com o direcionamento intracelular da proteína. Em plantas, a maioria das enzimas relacionadas à parede celular e membrana são $N$-glicosiladas. A seqüência reconhecida pelo aparato de glicosilação é N-X-S/T, onde X significa qualquer aminoácido menos prolina (Staehelin \& Moore, 1995). A atividade da UGPase ligada à membrana pode estar envolvida com o fornecimento de UDP-glicose para a biossíntese de componentes da parede celular, incluindo â-glucanos e celulose (Kleczkowski, 1994).

A partir da comparação das seqüências de aminoácidos da UGPase de plantas, animais e fungos, Flores-Díaz et al (1997) localizaram três motivos conservados. Os motivos foram definidos como sendo regiões com pelo menos 11 resíduos exatamente iguais ao longo de 30 resíduos consecutivos. Na proteína deduzida a partir do cDNA clonado foram encontradas três seqüências (91-122, 194-224, 338-367) (Figura 9) semelhantes aos motivos registrados por Flores-Díaz et al. e em posições praticamente idênticas (90-121, 193-223, 337-366). 




Figura 9- Seqüência de nucleotídeos e seqüência deduzida de aminoácidos do cDNA da UGPase clonado de tubérculo de batata. A sequiênc ia de nucleotídeos encontra-se numerada na direção 5' -3', e a sequiência de aminoácidos está numerada a partir do sítio de início de tradução. Na sequiência deduzida de aminoácidos, os motivos para N-glicosilação estão destacados em amarelo, os resíduos lisina, homólogos àqueles considerados de importância crítica para o funcionamento da UGPase em tubérculos de batata, estão circulados, e os motivos conservados estão em azul 


\subsection{Blast da seqüência do gene com o NCBI}

A análise da seqüência consenso por meio do programa BlastX revelou alta homologia (valor $\mathrm{E}=0.0$ ) com UGPases de diferentes cultivares de batata (Katsube et al, 1990; Spychalla et al., 1994, Borovkov et al., 1997; Sowokinos et al., 2002), bem como de outras espécies vegetais (Tabela 2).

Tabela 2. Homologia encontrada entre a sequiência de nucleotídeos do cDNA clonado e dados genéticos no GenBank através do programa BlastX

\begin{tabular}{|c|c|c|c|}
\hline Seqüência & Score & Valor E & Identidade * \\
\hline UGPase Solanum tuberosum gi|136739| & 816 & 0.0 & $90 \%$ \\
\hline UGPase Solanum tuberosum gi|1388021| & 815 & 0.0 & $90 \%$ \\
\hline UGPase Solanum tuberosum gi|322794| & 815 & 0.0 & $90 \%$ \\
\hline UGPase Solanum tuberosum gi|28863913| & 813 & 0.0 & $90 \%$ \\
\hline UGPase Solanum tuberosum gi|28863903| & 813 & 0.0 & $90 \%$ \\
\hline UGPase Solanum tuberosum gi|28863909| & 807 & 0.0 & $89 \%$ \\
\hline UGPase Amorpha fruticosa gi|17026394| & 692 & 0.0 & $77 \%$ \\
\hline UGPase Musa acuminata gi|12585489| & 689 & 0.0 & $77 \%$ \\
\hline UGPase Oryza sativa gi|15823775| & 686 & 0.0 & $78 \%$ \\
\hline UGPase Hordeum vulgare gi|6136111| & 684 & 0.0 & $77 \%$ \\
\hline UGPase Arabidopsis thaliana gi|15237947| & 682 & 0.0 & $76 \%$ \\
\hline UGPase Pyrus pyrifolia gi|6136112| & 673 & 0.0 & $77 \%$ \\
\hline UGPase Nicotiana tabacum gi|17402533| & 660 & 0.0 & $92 \%$ \\
\hline UGPase Pyrus pyrifolia gi|19911799| & 626 & e-178 & $72 \%$ \\
\hline
\end{tabular}

* Identidade dada pela porcentagem de aminoácidos idênticos. 


\subsection{Verificação de domínio conservado}

A proteína deduzida a partir da seqüência consenso de nucleotídeos do cDNA clonado de batata foi analisada quanto à presença de domínios funcionais através do programa Pfam. Observou-se que a proteína possui um único domínio conservado e completo, localizado entre os resíduos 32 e 445 (Figura 10) idêntico ao domínio encontrado para as UGPases de batata disponíveis nos bancos de dados. A seqüência foi identificada como pertencente à família de proteínas UDPGP (UDP-glicose pirofosforilases) com Score igual a 824.3, o que quer dizer que a comparação é altamente significativa.

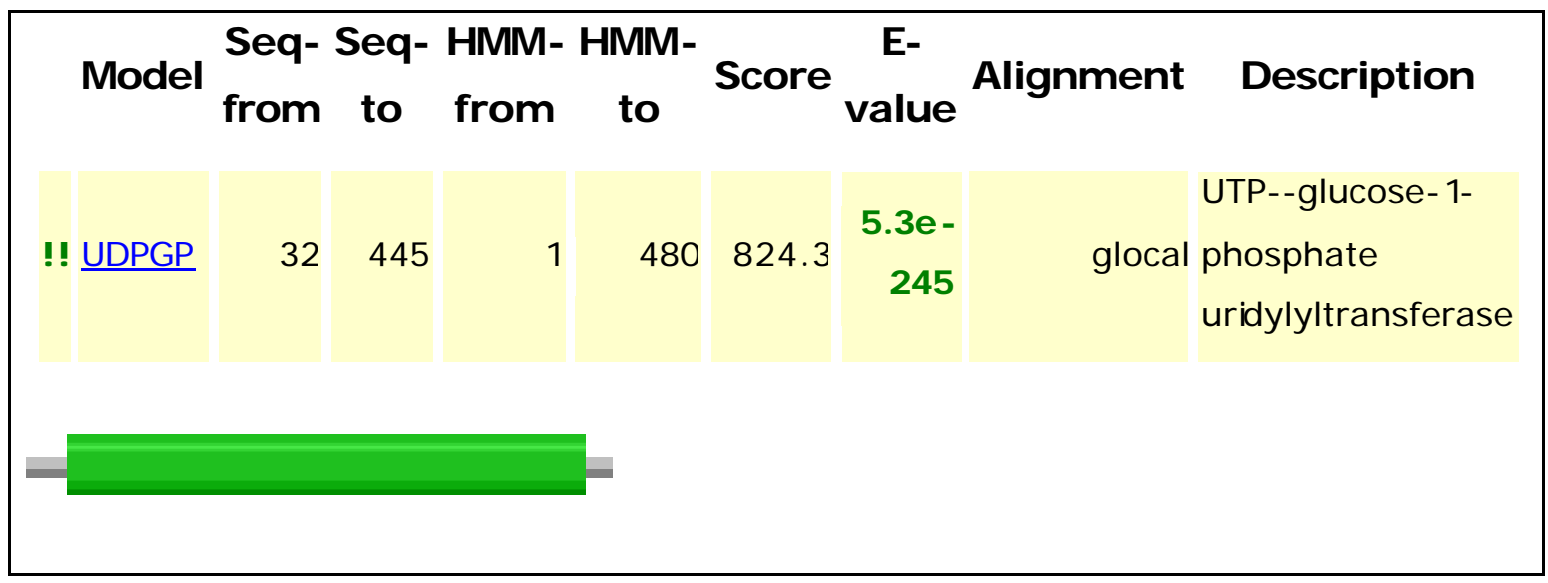

Figura 10- Representação diagramática da extensão do domínio UDPGP (em verde) em relação à seqüência deduzida a partir do cDNA codificador da UGPase de batata, obtida no programa Pfam. A figura é idêntica à de diferentes gi(s) da enzima em batata

\subsection{PCR de DNA genômico de E.grandis com primers de UGPase da batata}

Foi realizada a reação de PCR utilizando-se DNA genômico de E. grandis e par de primers específicos para o gene da UGPase definidos a partir de seqüências do gene 
em batata. A amplificação resultou em dois fragmentos, um de $1,3 \mathrm{~kb}$ e outro de $0,7 \mathrm{~kb}$ (Figura 11), aproximadamente. O tamanho do maior fragmento obtido é próximo ao esperado (1,4 kb) para cds encontrado entre cultivares de batata (Katsube et al., 1990; Spychalla et al., 1994; Sowokinos et al., 2002) e em outras espécies vegetais. Porém, é bem menor ao gene intercalado por íntrons (6,6 kb) de batata (Borovkov et al., 1997). O fragmento menor pode ter sido resultante de uma amplificação inespecífica.

O resultado obtido indica que o gene que codifica a UGPase está presente no genoma de eucalipto e que este pode ser amplificado por meio de PCR mesmo com os primers desenhados para a batata. Entretanto, as condições de amplificação precisam ser aprimoradas.

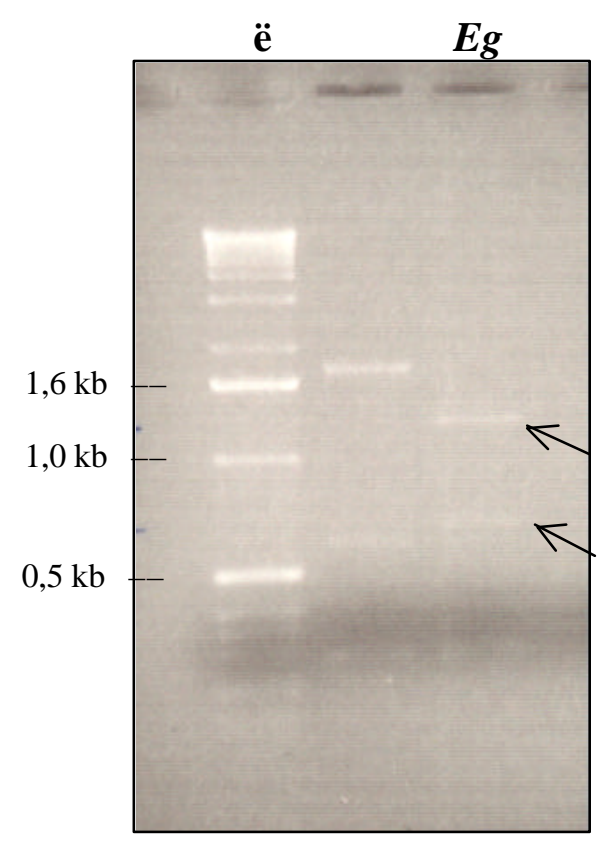

Figura 11- Perfil eletroforético do produto de PCR obtido na amplificação de DNA genômico de Eucalyptus grandis (Eg) com primers específicos para amplificar 


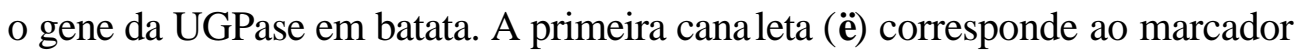
de peso molecular $1 \mathrm{~kb}$ DNA Ladder - Invitrogen

\subsection{Southern blot}

As enzimas escolhidas para a digestão de DNA genômico da batata e de eucalipto foram a PstI, uma vez que esta enzima encontra-se na relação de enzimas que não clivam a ORF das sequiências de vários gi(s) que contêm o gene da UGPase de batata, utilizados nas análises, e HindIII, que cliva a ORF duas ou três vezes, dependendo da seqüência.

Na Figura 12 é possível observar que a sonda produziu oito bandas no DNA genômico de S. tuberosum digerido com a enzima de restrição HindIII, e quatro bandas no digerido com PstI. Esse padrão de bandas na análise de Southern blot pode ser devido à presença de íntrons no gene de interesse, que possuam sítios internos de restrição específicos para as enzimas HindIII e PstI, não visualizados no padrão de digestão simulado para a ORF.

A presença de várias bandas também pode ser um indício da ocorrência de isoformas da enzima UGPase. Segundo Sowokinos et al, (1997) as seqüencias encontradas em diferentes cultivares podem representar um polimorfismo alélico no gene, especialmente se a UGPase é codificada por um único gene em batata (Borovkov et al, 1986). O indicativo de que a UGPase se apresenta na forma de homodímero, como proposto por Sowokinos et al. (1993), reforça a idéia de polimorfismo alélico.

Também, a inibição antisense da expressão do gene que codifica a UGPase em tubérculos de batata levou a um decréscimo tanto dos níveis de mRNA como de proteína em todos os tecidos estudados de batata (Zrenner et al., 1993). Isto sugere ou a presença de um único gene $U g p$ em batata, ou a presença de uma família de genes que produzem transcritos altamente homólogos.

Eimert et al (1996) também concluíram que a UGPase é codificada por um único gene em cevada. No entanto, a hipótese de um único gene é difícil de se ajustar às evidências dadas pelo polimorfismo de comprimento de fragmento de restrição (RFLP) 
que indicam a presença de pelo menos três genes codando UGPase em cevada (Kleinhofs, citado por Eimert et al., 1996).

A presença de bandas na análise de Southern blot com DNA genômico de $E$. grandis indica que um gene que codifica a UGPase, semelhante ao que codifica a enzima em batata, está presente em seu genoma. Esta evidência é reforçada pelo fato de se ter obtido produto amplificado na reação de PCR descrita anteriormente.

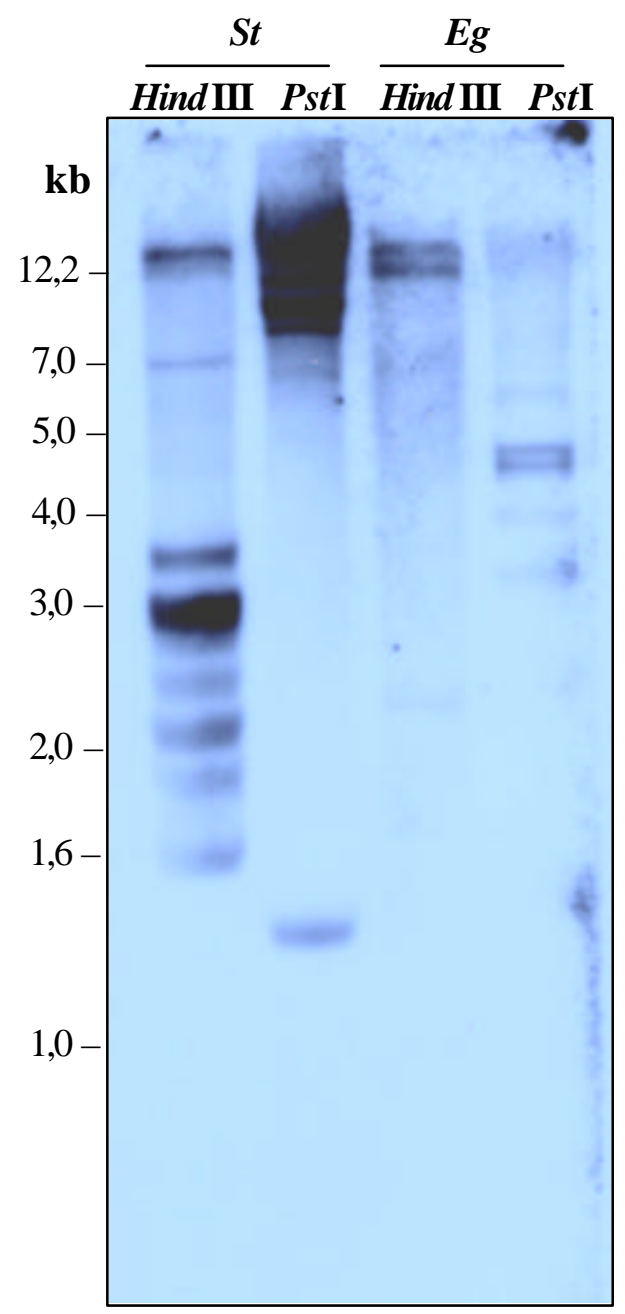


Figura 12- Análise de Southern blot do DNA genômico de Solanum tuberosum $(\boldsymbol{S t})$ e de Eucalyptus grandis (Eg) parcialmente digeridos com as enzimas de restrição HindIII e PstI. O produto da reação de RT-PCR da UGPase de batata foi utilizado como sonda 


\section{CONCLUSÕES}

A amplificação do produto de RT-PCR de $S$. tuberosum com o par de oligonucleotídeos iniciadores (primers) gerou um fragmento de aproximadamente 1.400 pares de bases correspondente à ORF que codifica a UGPase.

A ligação do produto de RT-PCR ao plasmídio pENTE/D-TOPO e posterior transformação de células TOP10 permitiu a obtenção de clones contendo o cDNA para a UGPase.

A sequiência de aminoácidos deduzida do cDNA clonado é altamente homóloga à UGPase de diferentes cultivares de batata e de outras espécies vegetais. 
ANEXOS 
ANEXO A. Código IUPAC de uma e de três letras para os aminoácidos

\begin{tabular}{|c|c|c|c|c|c|}
\hline \multicolumn{2}{|c|}{ Códigos } & Resíduo & \multicolumn{2}{|c|}{ Códigos } & Resíduo \\
\hline $\mathrm{A}$ & Ala & alanina & $\bar{P}$ & Pro & prolina \\
\hline B & Asx & aspartato or asparagina & Q & Gln & glutamina \\
\hline $\mathrm{C}$ & Cys & cisteína & $\mathrm{R}$ & Arg & arginina \\
\hline $\mathrm{D}$ & Asp & aspartato & S & Ser & serina \\
\hline $\mathrm{E}$ & Glu & glutamato & $\mathrm{T}$ & Thr & treonina \\
\hline $\mathrm{F}$ & Phe & fenilalanina & $\mathrm{U}$ & & selenocisteína \\
\hline G & Gly & glicina & V & Val & valina \\
\hline $\mathrm{H}$ & His & histidina & W & Trp & triptofano \\
\hline I & Ile & isoleucina & $X$ & Хаa & desconhecido \\
\hline K & Lys & lisina & Y & Tyr & tirosina \\
\hline $\mathrm{L}$ & Leu & leucina & $\mathrm{Z}$ & Glx & glutamato ou glutamina \\
\hline M & Met & metionina & $*$ & & fim de tradução \\
\hline $\mathrm{N}$ & Asn & asparagina & - & & $\begin{array}{l}\text { intervalo de comprimento } \\
\text { indeterminado }\end{array}$ \\
\hline
\end{tabular}

ANEXO B. Nomenclatura IUB de bases em seqüência de ácidos nuclêicos

\begin{tabular}{llll}
\hline Código & Significado & Código & Significado \\
\hline A & adenina (A) & M & amino (A ou C) \\
C & citosina (C) & S & forte (G ou C) \\
G & guanina (G) & W & fraco (A ou T) \\
T & timina (T) & B & G ou T ou C \\
U & uracila (U) & D & G ou A ou T \\
R & purina (G ou A) & H & A ou C ou T \\
Y & pirimidina (T ou C) & V & G ou C ou A \\
K & keto (G ou T) & N & qualquer base (A, G, C ou T) \\
- & intervalo(s) & &
\end{tabular}


ANEXO C. Tampão de Extração de RNA

\begin{tabular}{lc}
\hline \multicolumn{1}{c}{ Componente } & Concentração final \\
\hline Tiocianato de guanidina & $4 \mathrm{M}$ \\
Tris- $\mathrm{HCl}$ & $0,1 \mathrm{M}$ \\
Citrato de sódio stock $0,5 \mathrm{M}$ & $25 \mathrm{mM}$ \\
N-lauryl sarcosine stock $10 \%$ & $0,5 \%$ \\
PVP & $1 \%$ \\
2-mercaptoetanol & $200 \mu \mathrm{l}$ \\
$\mathrm{H}_{2} \mathrm{O}$ DEPC $0,1 \%$ & q.s.p. $10 \mathrm{ml}$ \\
\hline
\end{tabular}

\section{ANEXO D. Tampão TAE $1 \mathrm{X}$}

\begin{tabular}{lc}
\hline \multicolumn{1}{c}{ Componente } & Quantidade \\
\hline Tris base & $4,84 \mathrm{~g}$ \\
Ácido acético glacial & $1,14 \mathrm{ml}$ \\
EDTA $0,5 \mathrm{M} \mathrm{pH} 8.0$ & $2 \mathrm{ml}$ \\
Ajustar pH 8.0 & \\
Água destilada & q.s.p. $1 \mathrm{~L}$ \\
\hline
\end{tabular}

ANEXO E. Tampão de ligação (Binding buffer) para purificação de mRNA (de acordo com kit Dynabeads ${ }^{\circledR}$ mRNA Purification da Dynal

\begin{tabular}{lc}
\hline \multicolumn{1}{c}{ Componente } & Concentração Final \\
\hline Tris-HCl (pH 7.5) & $20 \mathrm{mM}$ \\
$\mathrm{LiCl}$ & $1,0 \mathrm{M}$ \\
EDTA & $2 \mathrm{mM}$ \\
Água MilliQ tratada com DEPC & q.s.p. $4 \mathrm{ml}$ \\
Autoclavar & \\
\hline
\end{tabular}


ANEXO F. Tampão de lavagem B para purificação de mRNA (de acordo com kit Dynabeads ${ }^{\circledR}$ mRA Purification da Dynal

\begin{tabular}{lc}
\hline \multicolumn{1}{c}{ Componente } & Concentração Final \\
\hline Tris-HCl (pH 7.5) & $10 \mathrm{mM}$ \\
$\mathrm{LiCl}$ & $0,15 \mathrm{M}$ \\
EDTA & $1 \mathrm{mM}$ \\
Água MilliQ tratada com DEPC & q.s.p. $4 \mathrm{ml}$ \\
Autoclavar & \\
\hline
\end{tabular}

ANEXO G. Tampão TBE 0,5 X (Sambroock et al, 1989)

\begin{tabular}{lc}
\hline \multicolumn{1}{c}{ Componente } & Quantidade \\
\hline Tris base & $5,4 \mathrm{~g}$ \\
Ácido bórico & $2,75 \mathrm{~g}$ \\
EDTA $0,5 \mathrm{M} \mathrm{pH} 8.0$ & $2 \mathrm{ml}$ \\
Água destilada & q.s.p. $1 \mathrm{~L}$ \\
\hline
\end{tabular}

ANEXO H. Tampão da amostra (Dye IV - Sambroock et al, 1989)

\begin{tabular}{lc}
\hline \multicolumn{1}{c}{ Componente } & Concentração Final (p/v) \\
\hline Sacarose & $40 \%$ \\
Azul de bromofenol & $0,25 \%$ \\
Água MilliQ estéril & q.s.p. $1 \mathrm{ml}$ \\
\hline
\end{tabular}


ANEXO I. Master Mix para PCR

\begin{tabular}{|c|c|c|}
\hline \multicolumn{2}{|c|}{ Componente } & Concentração final \\
\hline \multicolumn{2}{|c|}{ Água MilliQ estéril } & q.s.p. $50 \mu l$ \\
\hline \multicolumn{2}{|c|}{ Tampão de reação $10 \mathrm{X}$} & $5,0 \mu \mathrm{l}$ \\
\hline \multicolumn{2}{|l|}{$\mathrm{MgCh}$} & $1,5-2,5 \mathrm{mM}$ \\
\hline & A & $200 \mu \mathrm{M}$ \\
\hline \multirow[t]{3}{*}{ dNTPs } & $\mathrm{C}$ & $200 \mu \mathrm{M}$ \\
\hline & G & $200 \mu \mathrm{M}$ \\
\hline & $\mathrm{T}$ & $200 \mu \mathrm{M}$ \\
\hline \multicolumn{2}{|c|}{ PrimerSense } & 50 pmoles \\
\hline \multicolumn{2}{|c|}{ PrimerAntisense } & 50 pmoles \\
\hline \multicolumn{2}{|l|}{ DNA } & q.s.p. $100 \mathrm{ng}$ \\
\hline \multicolumn{2}{|c|}{ Taq polimerase $(5 \mathrm{U} / \mu \mathrm{l})$} & $1 \mathrm{U}$ \\
\hline
\end{tabular}

ANEXO J. Meio SOC

Componente

Concentração Final

\begin{tabular}{lr}
\hline Bacto triptona & $2 \%(\mathrm{p} / \mathrm{v})$ \\
Bacto extrato de levedura & $0,5 \%(\mathrm{p} / \mathrm{v})$ \\
$\mathrm{NaCl}$ & $10 \mathrm{mM}$ \\
$\mathrm{KCl}$ & $2,5 \mathrm{mM}$ \\
$\mathrm{MgCb}$ & $10 \mathrm{mM}$ \\
$\mathrm{MgSO}_{4}$ & $10 \mathrm{mM}$ \\
Glicose & $20 \mathrm{mM}$ \\
Água MilliQ & q.s.p. $1 \mathrm{~L}$ \\
\hline
\end{tabular}


ANEXO K. Meio LB

\begin{tabular}{lc}
\multicolumn{1}{c}{ Componente } & $p / v(\%)$ \\
\hline Bacto triptona & 1,0 \\
Bacto extrato de levedura & 0,5 \\
$\mathrm{NaCl}$ & 1,0 \\
Ágar bacteriológico (para meio sólido) & 1,0 \\
Ajustar pH 7.0 & \\
Água MilliQ & q.s.p. 1 L \\
\hline
\end{tabular}

ANEXO L. Tampão P1 (conforme protocolo do Plasmid Mini Kit da QIAGEN)

\begin{tabular}{lc}
\hline \multicolumn{1}{c}{ Componente } & Concentração Final \\
\hline Tris-HCl pH 8.0 & $50 \mathrm{mM}$ \\
EDTA & $10 \mathrm{mM}$ \\
Água MilliQ & q.s.p. $1 \mathrm{~L}$ \\
Ajustar pH 8.0 com HCl & \\
RNase (depois de autoclavar) & $100 \mu \mathrm{g} / \mathrm{ml}$
\end{tabular}

ANEXO M. Tampão P2 (conforme protocolo do Plasmid Mini Kit da QIAGEN)

\begin{tabular}{|c|c|}
\hline Componente & Concentração Final \\
\hline $\mathrm{NaOH}$ & $200 \mathrm{mM}$ \\
\hline SDS & $1 \%$ \\
\hline Água MilliQ estéril & q.s.p. $1 \mathrm{~L}$ \\
\hline
\end{tabular}


ANEXO N. Tampão P3 (conforme protocolo do Plasmid Mini Kit da QIAGEN)

\begin{tabular}{lc}
\hline \multicolumn{1}{c}{ Componente } & Concentração Final \\
\hline Acetato de potássio & $3,0 \mathrm{M}$ \\
Ajustar pH 5.5 com ácido acético glacial & \\
Água MilliQ estéril & q.s.p. 1 L \\
Esterilizar por filtragem (milipore $0,2 \mu \mathrm{m})$ & \\
\hline
\end{tabular}

ANEXO O. Solução QBT (conforme protocolo do Plasmid Mini Kit da QIAGEN)

\begin{tabular}{lc}
\hline \multicolumn{1}{c}{ Componente } & Concentração Final \\
\hline $\mathrm{NaCl}$ & $750 \mathrm{mM}$ \\
$\mathrm{MOPS}$ & $50 \mathrm{mM}$ \\
Ajustar $\mathrm{pH} 7.0$ & \\
Isopropanol puro & $15 \%$ \\
Triton $^{\circledR} \mathrm{X}-100$ & $0,15 \%$ \\
Água MilliQ & q.s.p. $1 \mathrm{~L}$ \\
Esterilizar por filtragem (milipore $0,2 \mu \mathrm{m})$ & \\
\hline
\end{tabular}

ANEXO P. Solução QC (conforme protocolo do Plasmid Mini Kit da QIAGEN)

\begin{tabular}{lc}
\hline \multicolumn{1}{c}{ Componente } & Concentração Final \\
\hline $\mathrm{NaCl}$ & $1,0 \mathrm{M}$ \\
$\mathrm{MOPS}$ & $50 \mathrm{mM}$ \\
Ajustar pH 7.0 & \\
Isopropanol puro & $15 \%$ \\
Água MilliQ & q.s.p. $1 \mathrm{~L}$ \\
Esterilizar por filtragem (milipore $0,2 \mu \mathrm{m})$ & \\
\hline
\end{tabular}


ANEXO Q. Solução QF (conforme protocolo do Plasmid Mini Kit da QIAGEN)

\begin{tabular}{lc}
\hline \multicolumn{1}{c}{ Componente } & Concentração Final \\
\hline $\mathrm{NaCl}$ & $1,25 \mathrm{M}$ \\
Tris- $\mathrm{HCl}$ & $50 \mathrm{mM}$ \\
Ajustar $\mathrm{pH} 8.5 \mathrm{com} \mathrm{HCl}$ & \\
Isopropanol puro & $15 \%$ \\
Água MilliQ & q.s.p. $1 \mathrm{~L}$ \\
Esterilizar por filtragem (milipore $0,2 \mu \mathrm{m})$ & \\
\hline
\end{tabular}

ANEXO R. Tampão de Extração de DNA (conforme Doyle \& Doyle, 1987)

\begin{tabular}{lr}
\hline \multicolumn{1}{c}{ Componente } & Concentração Final \\
\hline $\mathrm{NaCl}$ & $1.4 \mathrm{M}$ \\
Tris-HCl pH 8.0 & $100 \mathrm{mM}$ \\
EDTA pH 8.0 & $20 \mathrm{mM}$ \\
PVP-40 & $1 \%$ \\
CTAB & $2 \%$ \\
$\beta$-mercaptoetanol & $0.2 \%-1 \%$ \\
$\mathrm{H}_{2} \mathrm{O}$ MilliQ estéril & q.s.p.
\end{tabular}

ANEXO S. Tampão TE

\begin{tabular}{lc}
\hline Componente & Concentração Final \\
\hline Tris-HCl pH 8.0 & $10 \mathrm{mM}$ \\
EDTA pH 8.0 & $1 \mathrm{mM}$ \\
Água MilliQ & q.s.p. \\
\hline
\end{tabular}


ANEXO T. Solução 20 X SSC (conforme protocolo Hybond da Amersham Pharmacia)

\begin{tabular}{lc}
\hline \multicolumn{1}{c}{ Componente } & Concentração Final \\
\hline $\mathrm{NaCl}$ & $3 \mathrm{M}$ \\
$\mathrm{Na}_{3}$ Citrate dihidratado & $0,3 \mathrm{M}$ \\
Ajustar pH 7.0 & \\
Água MilliQ & q.s.p. 1 L
\end{tabular}

Obs.: As soluções 5 X SSC, 1 X SSC e 0,5 X SSC foram preparadas a partir da diluição da solução 20 X SSC em MilliQ estéril.

ANEXO U. Solução de pré-hibridização para Southern blot (conforme protocolo Hybond da Amersham Pharmacia)

\begin{tabular}{lr}
\multicolumn{1}{c}{ Componente } & Quantidade \\
\hline Dextran sulfato de sódio & $1 \%(\mathrm{p} / \mathrm{v})$ \\
Agente bloqueador de marcação (kit) & $1 \mathrm{ml}$ \\
SDS & $0,1 \%(\mathrm{p} / \mathrm{v})$ \\
Solução 5 X SSC & q.s.p. $20 \mathrm{ml}$ \\
\hline
\end{tabular}

ANEXO V. Buffer A (conforme protocolo Hybond da Amersham Pharmacia)

\begin{tabular}{lc}
\hline \multicolumn{1}{c}{ Componente } & Concentração Final \\
\hline Tris base & $100 \mathrm{mM}$ \\
$\mathrm{NaCl}$ & $300 \mathrm{mM}$ \\
Ajustar pH 9.0 & \\
Água MilliQ & q.s.p. $400 \mathrm{ml}$ \\
\hline
\end{tabular}




\section{REFERÊNCIAS BIBLIOGRÁFICAS}

ALTSCHUL, S.F.; MADDEN, T.L.; SCHÄFFER, A.A.; ZHANG, J.; ZHANG, Z.; MILLER, W.; LIPMAN, D.J. Gapped BLAST and PSI-BLAST: a new generation of protein database search programs. Nucleic Acids Research, v.25, n.17, p.3389-3402, 1997.

AMINO, S.; TAKEUCHI, Y.; KOMAMINE, A. Changes in enzyme activities involved in formation and interconversion of UDP-sugars during the cell cycle in a synchronous culture of Catharanthus roseus. Physiologia Plantarum, v.64, n.1, p.111-117, 1985.

BAR-PELED, M.; GRIFFITH, C.L.; DOERING, T.L. Functional cloning and characterization of a UDP-glucuronic acid decarboxylase: The pathogenic fungus Cryptococcus neoformans elucidates UDP-xylose synthesis. Proceedings of National Academy of Sciences of the United States of America, v.98, n.21, p.12003-12008, Oct. 2001.

BATEMAN, A.; BIRNEY, E.; CERRUTI, L; DURBIN, R.; ETWILLER, L.; EDDY, S.R.; GRIFFITHS-JONES, S.; HOWE, K.L.; MARSHALL, M.; SONNHAMMER, E.L.L. The Pfam protein families database. Nucleic Acids Research v.30, n.1, p.276-280, Jan. 2002.

BOROVKOV, A.Y.; MCCLEAN, P.E.; SECOR, G.A. Organization and transcription of the gene encoding potato UDP-glucose pyrophosphorylase. Gene, v.186, n.2, p.293297, Feb. 1997. 
BOROVKOV, A.Y.; MCCLEAN, P.E.; SOWOKINOS, J.R.; RUUD, S.H.; SECOR, G.A. Effect of expression of UDP-glucose pyrophosphorylase ribozyme and antisense RNAs on the enzyme activity and carbohydrate composition of field-grown transgenic potato plants. Journal of Plant Physiology, v.147, n.6, p.644-652, Mar. 1996.

CIERESZKO, I; JOHANSSON, H.; HURRY, V.; KLECZKOWSKI, L.A. Phosphate status affects the gene expression, protein content and enzymatic activity of UDPglucose pyrophosphorylase in wild-type and pho mutants of Arabidopsis. Planta, v.212, n.4, p.598-605, Mar. 2001b

CIERESZKO, I.; JOHANSSON, H.; KLECZKOWSKI, L.A. Sucrose and light regulation of a cold-inducible UDP-glucose pyrophosphorylase gene via a hexokinase-independent and abscisic acid-insensitive pathway in Arabidopsis. The Biochemical Journal, v.354, p.67-72, Feb. 2001a.

DALESSANDRO, G.; NORTHCOTE, D.H. Changes in enzymatic activities of nucleoside diphosphate sugar interconversions during differentiation of cambium to xylem in sycamore and poplar. The Biochemical Journal, v.162, p.267-279, 1977b.

DALESSANDRO, G.; NORTHCOTE, D.H. Possible control sites of polysaccharide synthesis during cell growth and wall expansion of pea seedlings (Pisum sativum L.) Planta, v.134, p.39-44, 1977a.

DARAN, J.M.; DALLIES, N.; THINES-SEMPOUX, D.; PAQUET, V.; FRANÇOIS, J. Genetic and biochemical characterization of the UGP1 gene encoding the UDPglucose pyrophosphorylase from Saccharomyces cerevisiae. European Journal of Biochemistry, v.233, n.2, p.520-530, Oct. 1995.

DELMER, D.P. Cellulose biosynthesis in developing cotton fibers. In: BASRA, A.S. (Ed.) Cotton Fibers. New York: Hayworth/Food Sci. Press, 1999b. p.85-102.

DELMER, D.P. Cellulose synthesis: Exciting times for a difficult field. Annual review of plant physiology and plant molecular biology, v.50, p.245-276, 1999a.

DELMER, D.P.; HAIGLER, C.H. The regulation of metabolic flux to cellulose, a major sink for carbon in plants. Metabolic Engineering, v.4, p.22-28, 2002. 
DIMOND, R.L.; FARNSWORTH, P.A.; LOOMIS, W.F. Isolation and chacacterization of mutations affecting UDPG pyrophosphorylase activity in Dictyostelium discoideum. Developmental Biology, v.50, p.169-181, 1976.

DOYLE, J.J.T.; DOYLE, J.L. Isolation of plant DNA from fresh tissue. Focus, v.12, p.13-15, 1987.

EIMERT, K.; VILLAND, P.; KILIAN, A.; KLECZKOWSKI, L.A Cloning and characterization of several cDNAs for UDP-glucose pyrophosphorylase from barley (Hordeum vulgare) tissues. Gene, v.170, n.2, p.227-232, May 1996.

FLORES-DIAZ, M.; ALAPE-GIRÓN, A.; PERSSON, B.; POLLESELlO, P.; MOOS, M.; VON EICHEL-STREIBER, C.; THELESTAM, M.; FLORIN, I. Cellular UDPglucose deficiency caused by a single point mutation in the UDP-glucose pyrophosphorylase gene. The Journal of Biological Chemistry, v.272, n.38, p.23784-23791, Sep. 1997.

FOSTER, G.D.; TWELL, D. (Eds.) Plant gene isolation: principles and practice. New York: Chichester/ John Wiley, 1996, cap.4

HAIGLER, C.H.; IVANOVA-DATCHEVA, M.; HOGAN, P.S.; SALNIKOV, V.V.; HWANG, S.; MARTIN, .K.; DELMER, D.P. Carbon partitioning to cellulose synthesis. Plant Molecular Biology, v.47, p.29-51, 2001.

HERTZBERG, M.; ASPEBORG, H.; SCHRADER, J.; ANDERSSON, A.; ERLANDSSON, R.; BLOMQVIST, K.; BHALERAO, R.; UHLEN, M.; TEERI, T.T.; LUNDEBERG, J.; SUNDBERG, B.; NILSSON, P.; SANDBERG, G. A transcriptional roadmap to wood formation. Proceedings of National Academy of Sciences of the United States of America, v.98, n.25, p.14732-14737, Dec. 2001.

HOSSAIN, S.A.; TANIZAWA, K.; KAZUTA, Y.; FUKUI, T. Overproduction and characterization of recombinant UDP-glucose pyrophosphorylase from Escherichia coli K-12. The Journal of Biochemistry. 115, p.965-972, 1994. 
INNIS, M.A.; GELFAND, D.H. Optimization of PCR. In: INNIS, M.A.; GELFAND, D.H.; SNINSKY, J.J.; WHITE, T.J. (Eds.) PCR protocols: a guide to methods and applications. San Diego: Academic Press, 1990, cap.1.

KANEHISA, M.; GOTO, S.; KAWASHIMA, S.; NAKAYA, A. The KEGG databases at GenomeNet. Nucleic Acids Research, v.30, n.1, p.42-46, Jan. 2002.

KARIMI, M.; INZÉ, D.; DEPICKER, A Gateway vectors for Agrobacterium-mediated plant transformation. Trends in Plant Science, v.7, n.5, p.193-195, May 2002.

KATSUBE, T.; KAZUTA, Y.; MORI, H., NAKANO, K., TANIZAWA, K.; FUKUI, T. UDP-glucose pyrophosphorylase from potato tuber: cDNA cloning and sequencing. The Journal of Biochemistry, v.108, n.2, p.321-326, 1990.

KATSUBE, T.; KAZUTA, Y.; TANIZAWA, K.; FUKUI, T. Expression in Escherichia coli of UDP-glucose pyrophosphorylase cDNA from potato tuber and functional assessment of the five lysyl residues located at the substrate-binding site. Biochemistry, v.30, n.35, p.8546-8551, Sep. 1991.

KAZUTA, Y.; OMURA, Y.; TAGAYA, M.; NAKANO, K.; FUKUI, T. Identification of lysyl residues located at the substrate-biding site in UDP-glucose pyrophosphorylase from potato tuber: affinity labeling with uridine di and triphosphopyridoxals. Biochemistry, v.30, p.8541-8545, 1991.

KLECZKOWSKI, L.A. Glucose activation and metabolism through UDP-glucose pyrophosphorylase in plants. Phytochemistry, v.37, n.6, p.1507-1515, Dec. 1994.

KONISHI, Y.; TANIZAWA, K.; MUROYA, S.; FUKUI, T. Molecular cloning, nucleotide sequencing, and affinity labeling of bovine liver UDP-glucose pyrophosphorylase. Journal of Biochemistry, v.114, p.61-68, 1993.

LEE, C.C.; CASKEY, C.T. cDNA cloning using degenerate primers. In: INNIS, M.A.; GELFAND, D.H.; SNINSKY, J.J.; WHITE, T.J. (Eds.) PCR protocols: a guide to methods and applications. San Diego: Academic Press, 1990, cap.6. 
LOEWUS, F.A.; KELLY, S.; NEUFELD, E.F. Metabolism of myo-inositol in plants: conversion to pectin, hemicellulose, D-xylose, and sugar acids. Proceedings of National Academy of Sciences of the United States of America, v.48, p.421-425, 1962.

LOEWUS, F.A; MURTHY, P.P.N. Myo-Inositol metabolism in plants. Plant Science, v.150, p.1-19, 2000.

NAKANO, K.; MORI, H.; FUKUI, T. Molecular cloning of cDNA encoding potato amyloplast $\alpha$-glucan phosphorylase and the structure of its transit peptide. The Journal of Biochemistry, v.106, p.691-695, 1989b.

NAKANO, K.; OMURA, Y.; TAGAYA, M.; FUKUI, T. UDP-glucose pyrophosphorylase from potato tuber: purification and characterization. The Journal of Biochemistry, v.106, n.3, p.528-532, 1989a.

PENG, H.L.; CHANG, H.Y. Cloning of human liver UDP-glucose pyrophosphorylase cDNA by complementation of the bacterial galU mutation. FEBS Letters, v.329, p.153-158, 1993.

PICTON, S.; GRAY, J.; BARTON, S.; ABUBAKAR, U.; LOWE, A.; GRIERSON, D. cDNA cloning and characterization of novel ripening-related mRNAs with altered patterns of accumulation in the ripening inhibitor (rin) tomato ripening mutant. Plant Molecular Biology, v.23, p.193-207, 1993.

PlOMiOn, C.; LEPROVOST, G.; STOKES, A. Wood formation in trees. Plant Physiology, v.127, p.1513-1523, Dec. 2001.

PUA, E.C.; LIM, S.S.W.; LIU, P.; LIU, J.Z. Expression of a UDPglucose pyrophosphorylase cDNA during fruit ripening of banana (Musa acuminata). Australian Journal of Plant Physiology, v.27, n.12, p.1151-1159, 2000.

REITER, W.D.; VANZIN, G.F. Molecular genetics of nucleotide sugar interconversion pathways in plants. Plant Molecular Biology, v.47, n.1-2, p.95-113, 2001. 
ROBERTS, R.M.; LOEWUS, F. The conversion of D glucose-6- $\left[{ }^{14} \mathrm{C}\right]$ to cell wall polysaccharide material in Zea mays in the presence of high endogenous levels of myo-inositol. Plant Physiology, v.52, p.646-650, 1973.

ROBERTSON, D.; BEECH, I.; BOLWELL, G.P. Regulation of the enzymes of UDPsugar metabolism during differentiation of french bean. Phytochemistry, v.39, n.1, p.21-28, 1995.

SALZMAN, R.A.;FUJITA, T.; ZHU-SALZMAN, K.; HASEGAWA, P.M.; BRESSAN, R.A. An improved RNA isolatio $n$ method for plant tissues containing high levels of phenolic compounds or carbohydrates. Plant Molecular Biology Reporter, v.17, p.11-17, 1999.

SAMBROOK, J.; FRITSCH, E.F.; MANIATIS, T. (Eds.) Molecular cloning: a laboratory manual. 2.ed. New York: Cold Spring Harbor Laboratory Press, 1989. 3v.

SCHARF, S.J.; HORN, G.T.; ERLICH, H.A. Direct cloning and sequence analysis of enzymatically amplified genomic sequences. Science, v.233, p.1076-1078, Sep. 1986.

SCHARF, S.J. Cloning with PCR. In: INNIS, M.A.; GELFAND, D.H.; SNINSKY, J.J.; WHITE, T.J. (Eds.) PCR protocols : a guide to methods and applications. San Diego: Academic Press, 1990, cap.11.

SOUTHERN, E.M. Detection of specific sequences among DNA fragments separated by gel electrophoresis. Journal of Molecular Biology, v.98, p.503-517, 1975.

SOWOKINOS, J.R.; SPYCHALLA, J.P.; DESBOROUGH, S.L. Pyrophosphorylases in Solanum tuberosum IV. Purification, tissue localization and physicochemical properties of UDP-glucose pyrophosphorylase. Plant Physiology, v.101, p.10731080, 1993.

SOWOKINOS, J.R.; THOMAS, C.; BURRELL, M.M. Pyrophosphorylases in potato. V. Allelic polymorphism of UDP-glucose pyrophosphorylase in potato cultivars and its association with tuber resistance to sweetening in the cold. Plant Physiology, v.113, n.2, p.511-517, Feb. 1997. 
SPYCHALLA, J.P.; SCHEFFLER, B.E.; SOWOKINOS, J.R.; BEVAN, M.W. Cloning, antisense RNA inhibition, and the coordinated expression of UDP-glucose pyrophosphorylase with starch biosynthesis gene in potato tubers. Journal of Plant Physiology, v.144, n.4-5, p.444-453, 1994.

STAEHELIN, L.A.; MOORE, I. The plant Golgi apparatus: structure, functional organization and trafficking mechanisms. Annual Review of Plant Physiology and Plant Molecular Biology, v.46, p.261-288, 1995.

THOMPSON, J.D.; HIGGINS, D.G.; GIBSON, T.J. CLUSTAL W: improving the sensitivity of progressive multiple sequence aligment through sequence weighting, position-specific gap penalties and weigh matrix choice. Nucleic Acids Research, v.22, p.4673-4680, 1994.

VALLA, S.; COUCHERON, D.H.; FJAERVIK, E.; KJOSBAKKEN, J.; WEINHOUSE, H.; ROSS, P.; AMIKAM, D.; BENZIMAN, M. Cloning of a gene involved in cellulose biosynthesis in Acetobacter xylinum: complementation of cellulose-negative mutants by the UDPG pyrophosphorylase structural gene. Molecular \& General Genetics, v.217, n.1, p.26-30, May 1989.

WITT, H.J. UDP-glucose metabolism during differentiation and dedifferentiation of Riella helicophylla. Journal of Plant Physiology, v.140, p.276-281, 1992.

ZRENNER, R.; WILLMITZER, L.; SONNEWALD, U. Analysis of the expression of potato uridinediphosphate-glucose pyrophosphorylase and its inhibition by antisense RNA. Planta, v.190, n.2, p.247-252, 1993. 